Izvorni znanstveni rad

Primljeno: 15 . svibnja 2018.

DOI: $10.20901 / \mathrm{pm} .55 .3 .01$

\title{
Još uvijek teorijska fantazija: egalitarni sindrom Josipa Županova
}

\author{
DANIJELA DOLENEC, DANIELA ŠIRINIĆ \\ Fakultet političkih znanosti, Sveučilište u Zagrebu
}

\begin{abstract}
Sažetak
U ovom tekstu analiziramo empirijski hommage Štulhofera i Burića (2015, 2016) Županovljevoj teoriji o egalitarnom sindromu (TES). Pokazujemo da autori preskaču neke fundamentalne korake u dizajnu istraživanja, kao što je zahtjev da propozicije vlastite teze uklope u postojeće znanje o nekoj temi. Nadalje, autori ne vode dovoljno računa o implikacijama višedimenzionalnosti konstrukta TES za svoju konceptualizaciju, a ni prilikom odabira statističkih analiza. Pokazujemo zašto podatke koje imaju ne bi trebali koristiti za analize koje poduzimaju. Nasuprot tome, naša analiza percepcije legitimne razine dohodovne nejednakosti sugerira da smo u europskim i globalnim okvirima sasvim prosječno egalitarno orijentirani. Dapače, stanovnici Njemačke ili Švicarske više teže uravnilovci nego stanovnici Hrvatske. Ovaj nalaz dovodi $\mathrm{u}$ pitanje interpretacije prema kojima je zahtjev za smanjenjem dohodovne nejednakosti atavizam socijalističke prošlosti, kao i one koje tvrde da takvi zahtjevi koče razvoj društva. Uzevši u obzir sve navedeno, zaključujemo da egalitarni sindrom i dalje ostaje teorijska fantazija.
\end{abstract}

Ključne riječi: teorija egalitarnog sindroma, modernizacijska teorija, dizajn istraživanja, dohodovna nejednakost, Hrvatska

\section{Uvod}

Josip Županov zaslužan je za nekoliko teza koje čine nezaobilazan okvir suvremenih društvenih znanosti u Hrvatskoj: o dominantnoj vrijednosti radikalnog egalitarizma, o egalitarnom sindromu kao prepreci razvoju, o "koaliciji nejednakih" između političke elite i radništva te o političkom ili “divljem” kapitalizmu. ${ }^{1}$ Županovljev opus,

1 Autorice na kritičkim komentarima žele zahvaliti Mirjani Kasapović, Goranu Čularu, Karin Doolan, Karlu Kralju, Marku Grdešiću, Kosti Bovanu, Mislavu Žitku te trima anonimnim recenzentima. Preostali propusti su, naravno, naši. 
dakle, sadržava važne ideje složene u kolaže koji su zanimljivi za čitanje, katkad nedosljedni, ali katkad daju precizne opise važnih društvenih problema. No, od vremena kada je nastao do danas, dijelom i autorovom zaslugom, Županovljev je rad prerastao u ready made objašnjenje za niz društvenih fenomena: socijalistička modernizacija iz vremena Jugoslavije bila je devijantna, a vrijednosni obrasci egalitarizma zaostali iz tog vremena sve do danas onemogućavaju razvoj. Tako je bivši potpredsjednik Vlade RH Borislav Škegro, referirajući se na egalitarni sindrom, nedavno napisao: ${ }^{2}$

Zastrašujuće. Društvo smo kojem je inherentan otpor promjenama i modernizaciji. Otpor rastu BDP-a, otpor investicijama, otpor zapošljavanju, otpor rastu životnog standarda, svemu, samo da se slučajno netko ne bi obogatio. Da ne bi ostvario profit. Pa neka sve propadne, barem ćemo tada biti jednaki u siromaštvu. Sociolozima predstoji golem posao. (...) Promjena će biti uspješna samo ako i kada se uništi sindrom sam, ili barem svede na marginu (istaknule autorice).

Kao što citat ilustrira, kulturološka objašnjenja, poput teorije egalitarnog sindroma, lako skliznu u esencijalizaciju, u ovom slučaju "naroda" kao neukog ili nazadnog. Ne čudi što ih izražavaju pripadnici političke elite, budući da ih takva dijagnoza ekskulpira od krivnje za trenutno stanje u društvu i istovremeno opravdava zahtjev za novim "strukturnim reformama". Problem je u tome što se velik broj hrvatskih društvenih znanstvenika desetljećima apologetski odnosi prema Županovljevim tezama, tretirajući ih kao neupitne istine.

Iako je svoj rad smještao u empirijsku sociologiju, pažljivim čitanjem i rekonstrukcijom teza iz ključnih Županovljevih radova s kraja šezdesetih godina Dolenec (2014) je ukazala na niz postupaka koji osporavaju empirijsku osnovu njegove teze o egalitarnom sindromu. Istraživanje provedeno u poduzećima u okolici Zagreba 1966. godine, koje predstavlja empirijski temelj njegovih tvrdnji - nužno je ponovno istaknuti - nije potvrdilo autorovu glavnu hipotezu da egalitarna norma utječe na dohodovne aspiracije. Bez obzira na to, Županov sljedećih tridesetak godina iz teksta $\mathrm{u}$ tekst prenosi to istraživanje kao empirijsku potvrdu svoje teze. U javnoj raspravi koja je uslijedila nakon što je objavljena kritika Dolenec (2014) isticano je kako nije korektno predbacivati Županovu što nije u svoje vrijeme primjenjivao statističke metode kakve su danas dostupne. No, Dolenec nije Županovu predbacila to što ne primjenjuje složene statističke tehnike, već je upozorila na nekorektnu primjenu osnovnih uzusa znanstvene metode, primjerice na korištenje nereprezentativnih podataka u dalekosežnim poopćavanjima, uspoređivanje neusporedivih podataka te donošenje zaključaka koji nisu u skladu s postojećim podacima (Levačić, 2016).

2 Večernji list, dostupno na https://www.vecernji.hr/premium/zastrasujuce-egalitarni-sindromglavni-je-uzrok-stava-da-ovdje-svi-moramo-biti-jednaki-u-siromastvu-1076911. Zadnji put pristupljeno 10. lipnja 2018. 
Kritički članak Dolenec (2014) potaknuo je akademsku i širu društvenu raspravu o egalitarnom sindromu ${ }^{3}$ te je u kratkom razdoblju objavljen niz radova koji se bave tom temom - Štulhofer i Burić (2015), Burić i Štulhofer (2016), Vuković, Štulhofer i Burić (2017), Burić (2017) te Rimac, Burić i Štulhofer (2017). Budući da su ti radovi nedvojbeno aktualizirali Županovljev rad, naše istraživačko pitanje u ovome članku glasi: jesu li i kako ti autori svojim analizama unaprijedili teoriju o egalitarnom sindromu (TES)? Iako je riječ o plodnoj suradnji koja je u nekoliko godina iznjedrila hvalevrijedan napor u prikupljanju novih anketnih podataka, ${ }^{4}$ izradu instrumenata i analiza te objavu više znanstvenih radova, u ovome radu želimo pokazati da temeljna pitanja povezana s TES-om ostaju otvorenima.

Želeći Županovu dati “empirijski hommage", navedeni autori u svojim radovima ciljaju izraditi "valjani mjerni instrument koji bi mogao poslužiti u širokom rasponu društvenih istraživanja” (Burić i Štulhofer, 2016: 3) i verificirati tezu o perzistenciji egalitarnog sindroma kao negativne kulturne inercije (Burić i Štulhofer, 2016; Vuković, Štulhofer i Burić; 2017 te Rimac, Burić i Štulhofer, 2017). ${ }^{5}$ Ovaj se tekst stoga fokusira na pitanje je li time doista napravljen empirijski hommage Županovljevoj teoriji. Ključni koraci kojima se "heuristički plodne teorije" (Štulhofer i Burić, 2015: 10) oblikuju u istraživački dizajn uključuju problemsku raspravu o literaturi na koju se neka teza nadovezuje, argumentiranje izbora metoda istraživanja, procese konceptualizacije i operacionalizacije te odluke o tome kako prikazati i tumačiti svoje nalaze. Navedena grupa autora, kao što pokazujemo, mnoge od tih koraka ne adresira.

Ovaj je članak strukturiran tako da u prvoj cjelini postavlja pitanja teorijske aktualizacije i istraživačkog dizajna koja autori zanemaruju, a u drugoj cjelini se bavi njihovim analitičkim odlukama i postupcima. Kako bismo rasvijetlile važna pitanja povezana s konceptualizacijom i izborom metoda istraživanja, u tekstu se krećemo između teza Josipa Županova s jedne strane te Štulhofera, Burića i njihovih suradnika s druge. Prvo otvaramo raspravu o tome kako Županovljeve teze korespondiraju s tezama klasične modernizacijske teorije i raspravljamo o implikacijama koje to ima za TES. Drugo, budući da je od nastanka modernizacijske teorije proteklo najmanje pola stoljeća, smatramo nužnim uzeti u obzir suvremena istraživanja utjecaja vrijednosti na društveni razvoj, poput onih koja se provode unutar globalnih

3 Za osvrte na javne rasprave organizirane u okviru Hrvatskog sociološkog društva vidi Doolan (2016) i Levačić (2016).

${ }^{4}$ Autorice zahvaljuju kolegama Aleksandru Štulhoferu i Ivanu Buriću što su nam ustupili svoje anketne podatke iz 2015. i 2016.

5 Burić (2017) u posebnom tekstu daje pregled teorijskih pristupa koji obrazlažu kauzalne mehanizme kulturne inercije, no pretpostavljamo da radovi koji će te teorijske uvide ugraditi u empirijske analize tek predstoje. 
istraživačkih programa kao što su World Value Survey i International Social Survey Project, te utvrditi do koje mjere TES s njima korespondira. U trećem dijelu teksta bavimo se komparativnom dimenzijom i dosegom teorije o egalitarnom sindromu. Za aktualizaciju TES-a čini nam se važnim izbaviti ga iz autarkičnog okvira u kojoj ostaje i nakon novoobjavljene serije tekstova. Stoga izvodimo komparativnu analizu stavova o dohodovnoj nejednakosti iz koje proizlazi da su stanovnici Hrvatske u europskim okvirima sasvim prosječno egalitarni. Riječ je o nalazu koji očito dovodi u pitanje omiljenu postavku u domaćim društvenim znanostima: ako, naime, stanovnici Njemačke i Francuske više teže egalitarnoj raspodjeli dohotka od stanovnika Hrvatske, možemo li i dalje tvrditi da je uravnilovka glavni kočničar razvoja hrvatskog društva? U posljednjem dijelu teksta analiziramo postupke operacionalizacije i statističke analize u tekstovima Štulhofer i Burić (2015) te Burić i Štulhofer (2016) ukazujući na probleme i slabosti iz kojih proizlazi da eventualna empirijska validacija egalitarnog sindroma tek predstoji.

\section{Egalitarni sindrom i modernizacijska teorija}

"Razvojna problematika", kako je zovu Štulhofer i Burić (2015: 11), velika je tema u društvenim znanostima koja se tiče načina na koji objašnjavamo "zašto su neke nacije neuspješne", ${ }^{6}$ odnosno pitanja možemo li identificirati, a onda i otkloniti prepreke uspješnijem društvenom razvoju. Katalog razmatranih utjecaja na društveni razvoj doista je opsežan, kao što su opsežne i rasprave o tome što pojam društvenog razvoja zapravo podrazumijeva ili treba podrazumijevati. To kompleksno područje može se učiniti preglednijim tako da se teorije svrstaju u tri temeljna pristupa: strukturalni, kulturološki i pristup racionalnog izbora (Lim, 2016). Strukturalni pristupi ukazuju na međuovisnost zemalja centra i periferije u globalno integriranoj ekonomiji te analiziraju obilježja političke ekonomije poput kvalitete institucija i utjecaja korupcije. Kulturološki pristupi sugeriraju da obilježja političke kulture presudno utječu na društveni razvoj. Racionalistički pristupi teže pak identificiranju preferencija ključnih aktera u danom kontekstu kako bi rasvijetlili logiku njihovog djelovanja. Tu je, naravno, i institucionalizam, danas dominantan pristup u politologiji i političkoj ekonomiji (Rhodes, 1995; Peters, 2007), no koji se u pravilu oslanja na pretpostavke nekog od navedena tri temeljna pristupa. Empirijske je analize tako obično moguće svrstati u historijski, sociološki ili institucionalizam racionalnog izbora (Hall i Taylor, 1996).

Klasična modernizacijska teorija, iz koje je izveden egalitarni sindrom, predstavlja kulturološko objašnjenje razlika u razvoju među zemljama. Riječ je o bo-

${ }^{6}$ Parafraza naslova utjecajne studije Acemoglu i Robinson (2012) Why Nations Fail: The Origins of Power, Prosperity, and Poverty. 
gatoj teorijskoj tradiciji koja usmjerava pažnju na ulogu kulturnih vrijednosti kao važnih poticaja odnosno prepreka razvoju i napretku. Ideja da su kulturne vrijednosti ključne za objašnjenje razvojnih putanja baštini dugu intelektualnu tradiciju koja potječe od Alexisa de Tocquevillea, Maxa Webera i Edwarda Banfielda (Harrison, 2000). U suvremenim društvenim znanostima uz kulturološki pristup se vežu znanstvenici globalnog utjecaja poput Samuela P. Huntingtona, Roberta Putnama, Ronalda Ingleharta i Francisa Fukuyame koji, na različite načine, zastupaju tezu o kulturološkim (vjerskim, civilizacijskim) razlikama kao uzroku različitih razina razvijenosti među društvima.

Takve analize obično rangiraju zemlje u svijetu na kontinuumu od "naprednih" do "nazadnih" na temelju implicitnih ili eksplicitnih "moralnih mapa" (Shweder, 2000). Napredak se nedvosmisleno sastoji u približavanju Zapadnoj Europi i SAD-u kako bi se što više nalikovalo na njih (Lim, 2010). Društva koja se žele modernizirati trebaju emulirati američki put, prije svega kroz napore vlastitih elita, ili ostati u nišama, svojevrsnim "vremenskim crnim rupama" (Harrison, 1988). ${ }^{7}$ Drugim riječima, modernizacijska teorija je nastala u političkom kontekstu Hladnog rata. Razvijena je kako bi se opisali procesi kojima su se zemlje trećeg svijeta industrijalizirale i modernizirale. Istraživački cilj je bio analizirati nerazvijena društva fokusirajući se na "zapreke" zbog kojih ona ne mogu "dostići” razvijeni svijet (Šporer, 2001), a politički cilj je bio osujetiti globalno širenje komunizma ${ }^{8}$ (Zeman, 1998). No, iako nastaje u kontekstu Hladnog rata, modernizacijska teorija o tom političkom i ekonomskom kontekstu šuti, pripisujući društvene neuspjehe unutarnjim društvenim faktorima, odnosno elementima političke kulture (Harrison, 1988). U takvoj se perspektivi sustavno zanemaruje međunarodni kontekst društvenog razvoja, odnosno faktori poput kolonijalne povijesti, ekonomske globalizacije, odnosa međuzavisnosti između zemalja jezgre i periferije, kao i uvidi međunarodne političke ekonomije. ${ }^{9}$

${ }^{7}$ Kulturološki pristup, kada se primjenjuje na unutarnju društvenu dinamiku, koristi se kako bi se objasnile razlike između, na primjer, muškaraca i žena, proširenost siromaštva među Afroamerikancima u SAD-u, slab uspjeh etničkih manjinskih skupina u obrazovanju i slično. Drugim riječima, pod kulturološkim pristupom često se kriju esencijalizacije identiteta kojima se opravdavaju različiti oblici strukturne nejednakosti kao, na primjer, činjenica da nema mnogo žena na vodećim položajima ili da je siromaštvo značajno prisutnije među afroameričkom populacijom u odnosu na ukupnu američku populaciju. U tom je smislu naziv “kulturološki” svojevrstan misnomer jer je zapravo riječ o socijalno-darvinističkim objašnjenjima koja polaze od ideje urođenih razlika (rodnih, rasnih, etničkih, vjerskih itd.) među ljudima.

${ }^{8}$ Podnaslov jedne od najutjecajnijih studija iz tog vremena, knjige W. W. Rostowa (1960) The Stages of Economic Growth, glasi "A Non-Communist Manifesto".

${ }^{9}$ Iz perspektive modernizacijske teorije razvoj je sinonim za kapitalizam i liberalnu demokraciju koji su u pretpostavljenoj harmoniji. U tom pristupu nema rasprave o tome kako sustavna reprodukcija nejednakosti u kapitalizmu predstavlja prepreku stvarnom korištenju političkih i građanskih prava (Dolenec, 2013). 
Ovaj kratak uvid u značajke modernizacijske teorije jasno ukazuje na njezin snažan utjecaj na formulaciju teze o devijantnoj modernizaciji u društvenim znanostima u Jugoslaviji, u čijoj je popularizaciji Županov imao važnu ulogu (Dolenec, 2016). Prema Županovu (1987a), proces modernizacije u Jugoslaviji doveden je $u$ pitanje zbog službene ideologije egalitarizma. S takvim vrijednosnim kôdom socijalistička se modernizacija pokazala kao "tek polumodernizacija" (Županov, 1995: 10). Stvorena je kultura koja "onemogućuje priključak modernom svijetu, stvoren je socio-kulturni sustav koji je inkompatibilan s modernim ekonomskim razvojem" (ibid.: 64). Prema Županovu (ibid.: 168), u socijalističkoj je Hrvatskoj postignuta svojevrsna materijalna modernizacija: urbanizacija, nova podjela rada, rast obrazovanosti, industrijska stratifikacija, rast životnog standarda, ali je "politička kultura bila i ostala mješavina seljačkog egalitarizma i plemenskog autoritarizma" (ibid.: 57). S takvim vrijednosnim sustavom "cjelokupni se socijalistički projekt može shvatiti kao velika povijesna aberacija na putu modernizacije" (ibid.: 171). Županov opisanim devijacijama suprotstavlja egalitarizam američkog društva koji se temelji na nesputanoj aspiraciji i jednakosti šansi (Dolenec, 2014).

Domaće društvene znanosti sve do danas u velikoj mjeri slijede Županovljevo tumačenje društvenog razvoja kao devijantnog, što Dolenec (2016) argumentira kao praksu orijentalizacije, čije je glavno obilježje karakterizacija vlastitog naroda kao kulturološki inferiornoga. Već desetljećima domaće društvene znanosti tumače autohtone društvene procese prije svega kroz prizmu loše kopije zapadnog svijeta, "priključka" koji iznova iznevjeruje njihova očekivanja zbog svoje "nepovoljne kulturne matrice" (npr. Štulhofer, 2001; Ivanković i Šonje, 2011), koja nas drži u "vrijednosnoj zamci" (Štulhofer i Burić, 2015: 9). Širok društveni utjecaj tih teza odražava se u njihovoj zastupljenosti u javnoj sferi. Uz spomenuti citat bivšeg podpredsjednika vlade Borislava Škegre takvo razumijevanje ilustrira izjava bivšeg dugogodišnjeg predsjednika Hrvatske gospodarske komore i kandidata za funkciju predsjednika Republike Hrvatske Nadana Vidoševića, koji je u jednoj televizijskoj emisiji izjavio kako su Hrvati "lijen, neobrazovan narod koji nema radne navike i navikao je živjeti na tuđem novcu. I to je temeljni problem zbog kojega nijedna vlada nije u stanju riješiti prave probleme." ${ }^{\prime 10}$ Izvedenice teze o nepovoljnoj kulturnoj matrici možemo pronaći i u popularnom pojmu "uhljeba", kao i u ideji o Hrvatskoj kao Apsurdistanu u kojemu su ljudi "glupe ovce" koje se opiru racionalnim rješenjima (vidi Dolenec, 2013).

Štulhofer i Burić $(2015,2016)$, iako retorički teže otvaranju velikih tema o društvenom razvoju Hrvatske, ne sučeljavaju kulturološke pretpostavke moderniza-

${ }^{10}$ Nadan Vidošević, izjava u emisiji "Nedjeljom u 2" 2010. godine. 
cijske teorije s drugim teorijskim pristupima. ${ }^{11}$ Stoga u ovoj analizi ostavljamo po strani konkurentska objašnjenja proširenosti egalitarnih stavova ili komparativno lošeg razvojnog položaja Hrvatske. Čini nam se da je važno kritičku raspravu voditi na terenu koji su odredili sami autori, a to su u ovom slučaju postavke teorije modernizacije. Stoga u sljedećim ulomcima najprije uspoređujemo Županovljeve teze $\mathrm{s}$ klasičnim istraživanjima u modernizacijskoj teoriji, a potom se usredotočujemo na istraživanja unutar suvremene teorije modernizacije i načine na koje ona korespondiraju s radovima Štulhofera i suradnika.

\section{Sindrom modernosti i suvremena istraživanja vrijednosti}

Da bismo određenu tezu nazvali teorijom, njezine se propozicije moraju uklapati u postojeće znanje o nekoj temi; teorija koja ignorira dotad prikupljeno znanje i dokaze je oksimoron (King, Keohane i Verba, 1994). Prema tome, središnje pitanje na koje ovdje trebamo odgovoriti jest kako se TES uklapa u bogatu tradiciju istraživanja u modernizacijskoj teoriji.

U knjizi Becoming Modern, jednom od važnijih empirijskih doprinosa klasičnoj teoriji modernizacije, Inkeles i Smith (1974) analiziraju vrijednosne orijentacije u šest zemalja koje su tada kategorizirane kao zemlje u razvoju: Indiji, Bangladešu, Čileu, Argentini, Nigeriji i Izraelu. Njihova je središnja teza da postoji nešto što nazivaju sindromom opće modernosti. ${ }^{12}$ Upitnik koji su proveli u šest spomenutih zemalja sadržavao je 166 pitanja, pokrivajući teme kao što su obrazovne i profesionalne aspiracije, stavovi prema religiji, ženskim pravima, naciji, obitelji, potrošnji,

11 Zadržavajući se unutar kulturološkog pristupa, Burić i Štulhofer (2016) se pozivaju na Swidler (1986), koja o kulturi govori kao o "kutiji alata za individualne i kolektivne akcije" (2016: 4), ali ne uzimaju pritom u obzir činjenicu da Swidler kulturu analizira kao praksu, odnosno da za nju "strategije djelovanja" predstavljaju jedinice analize. Za razliku od Štulhofera, Burića i suradnika, čija se empirijska validacija egalitarnog sindroma potpuno oslanja na stavove koje pojedinci izražavaju u anketnim upitnicima, teorijski pristup koji predlaže Swidler (1986) ne tretira individualne vrijednosne orijentacije kao početnu točku svog kauzalnog objašnjenja. Drugim riječima, analitičari koji se odlučuju za kulturološka objašnjenja trebali bi voditi računa o antropološkom diktumu prema kojemu kulturu ima smisla proučavati samo kroz prakse, odnosno ljudsko ponašanje, a ne kroz deklaratorno izraženu suglasnost s nizom propozicija u upitniku (Shweder, 2000).

12 S obzirom na to da je Alex Inkeles već 1960. objavio rad "Industrial Man" u American Journal of Sociology, da u njegovoj teoriji o sindromu modernosti poduzeće ima središnju ulogu te da je Županov šezdesetih godina iscrpno pratio američku sociologiju i srodne znanosti (citira radove Parsonsa, Druckera, Croziera, Etzionija, Likerta, Walkera, Lipseta, Sinaia, Denisona, Bendixa, Lenskog, Davisa i Moorea, Smelsera te radove iz časopisa American Sociological Review i American Journal of Sociology), čini nam se plauzibilnim da je poznavao Inkelesov pojam "sindroma opće modernosti”. No, u Županovljevim radovima nismo pronašle referenciju na Inkelesov rad. 
osjećaj samopouzdanja, optimizma, povjerenja u znanost itd. Iz anketnih pitanja izrađena je aditivna ljestvica na kojoj jedan kraj kontinuuma predstavlja tradicionalnost, a drugi modernost. ${ }^{13}$ Njihov je glavni nalaz da je moderni čovjek "informirani građanin koji participira, ima razvijen osjećaj osobne efikasnosti; visoko je neovisan $\mathrm{i}$ autonoman $\mathrm{u}$ odnosu na tradicionalne nositelje autoriteta, posebno $\mathrm{u}$ odnosu na odluke o svom osobnom životu; spreman je za nova iskustva i ideje, odnosno relativno je otvoren i kognitivno fleksibilan" (ibid.: 290).

S obzirom na očitu sličnost između pojmova Inkelesovog sindroma modernosti i Županovljevog egalitarnog sindroma, vrijedi podcrtati temeljnu razliku između njihovih konceptualizacija. Kod Inkelesa i Smitha prepreku modernosti čini široka paleta tradicionalnih vrijednosti i orijentacija, a moderni čovjek je definiran prije svega kao autonomna i otvorena osoba, u čemu možemo prepoznati teorijska izvorišta budućih radova Ronalda Ingleharta. U usporedbi s time, Županovljeva formulacija, prema kojoj egalitarni sindrom predstavlja prepreku modernosti, dramatično sužava tezu svodeći širok sindrom modernosti na dvije-tri povezane teme: preferencije prema preraspodjeli, predrasude prema poduzetnicima i nepoštovanje vrijednosti ekspertize. Znači li to da dimenzije vrijednosti koje su bitne za modernizaciju drugih zemalja nisu bitne za Hrvatsku? Zašto su za Hrvatsku upravo odbacivanje državne intervencije te okrenutost tržištu i poduzetništvu presudni za dostizanje modernosti, kao što obrazlaže prvo Županov, a onda i Štulhofer i Burić? Iz modernizacijske teorije nije moguće izvesti tako suženu tezu o vrijednosnim pretpostavkama modernosti.

Osim toga, Županov sužava i drugi dio te "jednadžbe" svodeći modernost na zapadna tržišna društva (Dolenec, 2014). Nasuprot tome, Inkeles i Smith (1974: 298) argumentiraju kako "modernih ljudi ima u svakom društvu i oni mogu postati većina u svakom društvu bez obzira na povijesnu kulturnu tradiciju". Eksplicitno tematiziraju pitanje je li njihov "moderni čovjek" sazdan po slici kapitalističkog čovjeka (ibid.: 18) te pažljivo razvijaju mjere pomoću kojih bi identificirali karakteristike koje su jednako važne za funkcioniranje tadašnjih kapitalističkih i socijalističkih društava. Kako bi osigurali da se pod modernošću ne podrazumijeva isključivo kapitalizam te izbjegli zamku eurocentričnosti, odlučuju se za tvornicu kao središnji

${ }^{13}$ Kako bi se ilustrirala sofisticiranost toga empirijskog zahvata, vrijedi navesti nekoliko pitanja iz upitnika. Pitanje EF-1: Neki ljudi vole posao u kojem treba donositi mnogo zahtjevnih odluka. Drugi vole poslove gdje ne moraju često donositi zahtjevne odluke. Kakav posao Vi preferirate? Pitanje GO-3: Da ženska osoba intervjuira Vašu suprugu, mislite li da bi Vaša supruga na ova pitanja imala većinom iste odgovore kao i Vi, donekle slične ili sasvim različite? Pitanje TI-3: Zamislite da ste zaposlili nekoga. Biste li mu: a) odredili fiksan dnevni raspored rada, b) dopustili nešto slobode u načinu na koji organizira dnevne obveze ili c) prepustili njemu da rasporedi dnevne dužnosti dok god ispunjava ciljeve? 
organizacijski koncept svoje teorije. Polaze od pretpostavke da je industrijalizacija bitna sastavnica modernizacije, te da je stoga tvornica središnja moderna institucija (ibid.). Na taj način izvorište modernih vrijednosti smještaju u okvir koji obuhvaća različite ekonomske sustave. Njihove analize ukazuju na to da pomoću nekoliko temeljnih činjenica o čovjeku, kao što su razina obrazovanja, zanimanje i porijeklo, možemo prilično dobro predvidjeti njegovu modernost (ibid.: 281); s tim da je za njih stupanj obrazovanja najvažniji prediktor individualne modernosti.

Županov, dakle, reducira i nezavisnu i zavisnu varijablu u temeljnoj hipotezi modernizacijske teorije: sindrom modernosti svodi na egalitarni sindrom, a društveni razvoj na tržišno društvo. Znanstvenik koji je vlastito društvo opisivao kao devijantno svoju je teoriju tako razvio uz bitne devijacije od polazišta matične teorije na koju se naslanja, posuđujući ono što mu se sviđa, a zanemarujući ono što se ne uklapa u njegovu interpretaciju. Kod Štulhofera i Burića pak egalitarni sindrom ne objašnjava samo neuspješnu prilagodbu na tržišnu ekonomiju, nego i klijentelizam, državni paternalizam, iracionalnost teritorijalne strukture Hrvatske, hipertrofiju državnih institucija, preveliko oslanjanje na državu, ukupno previsoka državna izdvajanja, nefleksibilnost tržišta rada, kao i stavove prema Europskoj uniji (Burić i Štulhofer, 2016). Drugim riječima, dok je Županov zavisnu varijablu značajno reducirao, Burić i Štulhofer je pak neopravdano proširuju na čitav katalog problema. $\mathrm{Na}$ engleskom za takve situacije postoji prikladna izreka: kada imate samo čekić, svaki problem izgleda kao čavao. ${ }^{14}$ Istovremeno, Štulhofer i Burić $(2015,2016)$, poduzimajući empirijsku verifikaciju TES-a gotovo pedeset godina nakon njezinog nastanka, ne aktualiziraju ga unutar suvremenih međunarodnih i domaćih istraživanja u modernizacijskoj teoriji. Stoga u narednom dijelu teksta uspoređujemo TES s istraživanjima Ingleharta i Welzela (2007), koja se temelje na dugogodišnjem Inglehartovom projektu globalnog istraživanja vrijednosti World Value Survey. Njegov rad uzimamo kao globalno relevantnu suvremenu formulaciju modernizacijske teorije, stoga važnu i za domaća istraživanja te teme.

\section{Inglehartova teorija modernosti i važnost osjećaja egzistencijalne sigurnosti}

Inglehart i Welzel (2007: 35) polaze od pretpostavke da se modernizacija vrijednosti događa "jedino kada ljudi u danom društvu u duljim razdobljima imaju visoke razine gospodarskog napretka". Logika koja, prema mišljenju autora, povezuje elemente modernosti u sindrom jesu kulturne promjene "koje naglašavaju čovjekovu autonomiju, kreativnost i samoaktualizaciju te demokratizacija" (ibid.: 36). Nasuprot Inkelesu i Smithu (1974), kod Ingleharta i Welzela (2007) obrazovanje ostaje važan dio sindroma modernosti, ali mu oni dodaju procjenu o tome smatraju li ljudi

14 When all you have is a hammer, every problem looks like a nail. 
svoj opstanak sigurnim, odnosno osjećaju li se egzistencijalno ugroženima. Inglehart i Welzel (2007) smatraju razinu ozračja sigurnosti odnosno nesigurnosti u društvu u najmanju ruku jednako važnom u oblikovanju svjetonazora kao što je razina obrazovanja. Isto tako u novom radu Inglehart (2018) naglašava kako percepcije ekonomske i fizičke nesigurnosti pogoduju autoritarnosti i krutom slijeđenju normi, dok društva koja postižu visoke razine ekonomske i fizičke sigurnosti pokazuju više vrijednosti tolerancije, otvorenosti novim idejama te veću rodnu ravnopravnost.

Kako bi obrazložili odvojene učinke razine obrazovanja i osjećaja egzistencijalne sigurnosti na sindrom modernosti, Inglehart i Welzel (2007) navode primjer država bivše socijalističke Europe i Sovjetskog Saveza. Nakon Drugog svjetskog rata većina tih zemalja imala je veću stopu gospodarskog rasta od zapadnih demokracija, zajedno s razmjerno visokom razinom jednakosti dohotka i razvijenim socijalnim sustavom. Drugim riječima, socijalistička su društva postigla razmjerno visoku razinu egzistencijalne sigurnosti. Nasuprot tome, $u$ devedesetim godinama dogodio se drastičan pad standarda, stagnacija ili pad očekivanog trajanja života te traumatično iskustvo proisteklo iz sloma društvenih i političkih sustava. Iako su razine naobrazbe nastavile rasti, prevladavajući osjećaj sigurnosti i kontrole nad vlastitim životom drastično se smanjio. Stoga u tim društvima Inglehart i Welzel (2007) ukazuju na izraženi naglasak na vrednotama opstanka, odnosno stagnaciju ili regresiju prema tradicionalnim vrijednostima. Osim toga, autori dodaju kako je u tim društvima nakon osamdesetih godina porasla nejednakost, što stvara osnovu za nove dogme, među ostalim za desni populizam i razne oblike vjerskog fundamentalizma.

U nekoliko paragrafa koje u svojoj knjizi posvećuju postsocijalističkoj Europi, Inglehart i Welzel (2007) zapravo nude plauzibilno objašnjenje porasta tradicionalnih vrijednosti koji je evidentiran u komparativnim istraživanjima vrijednosti u tim zemljama. Štulhofer i Burić (2015: 27) raspravljaju o nesklonosti preuzimanju rizika samo kao o orijentaciji koja je "teško spojiva s duhom kapitalizma, no savršeno uskladiva s državnim paternalizmom”. Za razliku od Ingleharta i Welzela (2007), koji orijentacije prema egzistencijalnoj sigurnosti shvaćaju kao racionalnu strategiju u društvenom i političkom kontekstu postkomunizma, Štulhofer i Burić (2015) ih razumiju kao prepreku individualnoj inicijativi. S druge strane, Vuković, Štulhofer i Burić (2017) testiraju naslijeđe agrarne kulture i troškove tranzicijskog razdoblja kao konkurentska objašnjenja razlika u zastupljenosti egalitarnog sindroma na županijskoj razini. Troškove tranzicije, koje autori mjere indikatorima razlika u dohocima i razlika u udjelu nezaposlenih od kraja osamdesetih do kraja devedesetih godina, mogli bismo tumačiti kao srodne hipotezi Ingleharta i Welzela (2007) o tome da okolnosti egzistencijalne ugroze jačaju prisutnost tradicionalnih vrijednosti. No, 
kao što objašnjavamo u nastavku teksta, ta analiza stoji na klimavim osnovama, tako da pouzdanije testiranje Inglehartove hipoteze tek predstoji.

Ostaje otvoreno pitanje zašto se Štulhofer i Burić nisu koristili mjerama koje Inglehart razvija i unapređuje već desetljećima. O obrascima individualnih vrijednosnih orijentacija u Hrvatskoj sigurno možemo mnogo više naučiti primjenom međunarodno validiranih mjera nego izradom vlastitih instrumenata koje implementiramo samo u Hrvatskoj. Nova se pitanja otvaraju kada obratimo pozornost na operacionalizacije koje koriste Inglehart i Welzel (2007) da bi zahvatili sindrom modernosti. Njihov teorijski okvir uključuje dvije dimenzije: tradicionalne naspram sekularno-racionalnim vrijednostima i vrijednosti opstanka nasuprot ekspresivnim vrijednostima. U njihovoj operacionalizaciji prve dimenzije, tradicionalnost $-s e-$ kularnost, nema nijedne čestice koja mjeri nešto što bi bilo slično bilo kojoj komponenti egalitarnog sindroma. U drugoj dimenziji, vrijednosti opstanka nasuprot ekspresivnosti, od 31 čestice tri se odnose na preferencije državne intervencije u gospodarstvu. Drugim riječima, konceptualizacija modernosti Ingleharta i Welzela (2007) ne identificira egalitarizam kao važnu prepreku razvoju. Usporedna analiza njihove inačice suvremene modernizacijske teorije i pretpostavki ugrađenih u teoriju egalitarnog sindroma pokazuje vrlo malo dodirnih točaka.

Nadalje, Štulhofer i Burić propuštaju svoje istraživanje razmotriti u sklopu suvremenih domaćih istraživanja društvenih vrijednosti (npr. Šram, 2008; Sekulić, 2012; Šram, 2014; Sekulić, 2016; Švarc i Lažnjak, 2017) i raspraviti implikacije tih radova za status Županovljeve teorije egalitarnog sindroma. Možda Županovljeva teorija doista jest bolja ili prikladnija za objašnjenje prepreka modernizaciji u Hrvatskoj od svih konkurentskih istraživanja vrijednosti, ali ako je tako, autori su dužni to argumentirati. Kada autori navode kako "za razliku od vremena u kojem je Županov osmislio TES, danas dostupne statističke metode (...) omogućuju preciznu i pouzdanu provjeru teorijskog modela" (Štulhofer i Burić, 2015: 14), istovremeno derogiraju domaća i međunarodna istraživanja društvenih vrijednosti od sedamdesetih godina do danas kao nevažna te čine medvjeđu uslugu "heurističkoj plodnosti" (ibid.: 10) te teorije svodeći cijelu problematiku na dostupnost statističkih tehnika za njezinu analizu. Kao što pokazujemo u nastavku, zanemarivanje važnih domaćih i međunarodnih doprinosa toj temi odnosi se i na izostanak rasprave o komparativnoj dimenziji i dosegu TES-a.

\section{Komparativna dimenzija i doseg teorije egalitarnog sindroma}

Poput Inkelesa i Smitha (1974), i Županov je u svojim istraživanjima anketirao zaposlenike u tvornicama, ali ih nije uspoređivao sa seljacima i radnicima koji ne rade u tvornici da bi mogao identificirati razlike među tim grupama i tako saznati nešto o mogućim razlikama u prisutnosti tradicionalnih vrijednosti među seljacima i radni- 
cima. Osim toga, Inkeles i Smith (1974) su se upustili u komparativno istraživanje, uključivši u analizu šest zemalja čiji su izbor podrobno obrazložili. Županov se, nasuprot tome, nije bavio dosegom svoje teorije. Je li egalitarni sindrom fenomen koji pogađa samo Jugoslaviju, odnosno Hrvatsku? Imamo li teorijskih ili nekih drugih razloga očekivati da drugdje u svijetu vrijednosti povezane s razvojem osobne autonomije ponajprije određuju stupanj modernosti, ali da to nije bilo tako u Jugoslaviji, gdje je prepreku modernosti činio egalitarni sindrom?

Dolenec (2014) pokazuje da Županov nije mario za doseg svoje teorije o egalitarnom sindromu. To je važan problem jer bismo, budući da u društvenim znanostima u najvećoj mjeri koristimo teorije ograničenog dosega, trebali paziti da se ne upuštamo u neopravdana poopćavanja, ali i da doseg teorije ne ograničavamo na arbitraran način (Coppedge, 2012). Županov je zanemarivao i prvu i drugu poteškoću: iz istraživanja provedenih u tvornicama oko Zagreba izvodio je zaključke o jugoslavenskom društvu i tako neopravdano generalizirao uvide, da bi u kasnijim radovima arbitrarno suzio doseg svojih teza na Hrvatsku. Nije nam dao objašnjenje je li egalitarni sindrom samo jugoslavenski problem, niti se upuštao u usporedbe jugoslavenskih republika ili Jugoslavije s drugim zemljama. Jedina eksplicitna komparacija u njegovim radovima teorijske je prirode, a tiče se usporedbe "zdravog" američkog egalitarizma koji podrazumijeva jednakost šansi i devijantnog jugoslavenskog egalitarizma koji predstavlja jednakost ishoda, "uravnilovku", odnosno "jednakost siromaštva" (1987a).

Budući da je Županovljeva teza, u nedostatku eksplicitnih usporedbi, dovela do čvrsto usidrene ideje prema kojoj smo kao društvo devijantni, čini se iznimno važnim u reaktualizaciji njegove teorije ponuditi uvide koji će pretpostavljeni visoko izraženi egalitarizam stanovnika Hrvatske smjestiti u komparativni okvir. Jedan od neplaniranih učinaka hegemonije TES-a u domaćim društvenim znanostima jest $i$ autarkičnost tih istraživanja koja otežava komparativne analize. Umjesto da Hrvatsku analiziraju unutar matrice postojećih globalnih istraživanja o vrijednostima, poput World Value Survey, European Value Survey ili International Social Survey Project - koji sadržavaju Inglehartove mjere modernosti, kao i niz čestica povezanih s pitanjima socijalne pravednosti, poželjne razine nejednakosti dohotka i percepcije nejednakosti u širem smislu - domaće društvene znanosti, uključujući recentnu seriju radova Burića, Štulhofera i suradnika, odlučuju se za izradu vlastitih instrumenta koji učvršćuju autarkični karakter TES-a.

Budući da je cilj ovog rada raspraviti doprinos Štulhofera i Burića TES-u, nemamo prostora za cjelovit prikaz komparativnih istraživanja koja se bave navedenim temama. Ograničavamo se stoga na analizu dimenzije koja čini jezgru Županovljeva radikalnog egalitarizma - aspiracije o dohotku. Najprije ćemo prikazati originalnu Županovljevu analizu, a zatim izvesti komparativnu analizu percepcije pravednosti raspodjele dohotka. 


\section{Opravdane i neopravdane nejednakosti dohotka-nekad i sad}

U ljeto 1969. Tadić i Županov su objavili tekst koji čini empirijski temelj teze da radikalni egalitarizam slabi individualne aspiracije, čime koči cijelo društvo. Autori su pošli od pretpostavke da norma egalitarnosti "limitira ne samo nominalne već i aspiracione zarade" (1969: 281). Drugim riječima, tvrde da "norma egalitarnosti djeluje tako da pojedinac ne samo da ne smije dobiti 'preveliku' zaradu, nego je čak ne smije ni željeti” (ibid.). Prisutnost društvene vrednote egalitarnosti testirali su kombinacijom dvaju pitanja u upitniku: ${ }^{15}$ "S obzirom na troškove života najniža zarada u poduzeću ne bi trebala biti niža od___ " i "Koliko bi po vašem mišljenju smjela iznositi najveća zarada u Vašem poduzeću: najveća zarada ne bi smjela biti veća od __." Ispitanike su grupirali prema tome jesu li izrazili nizak poželjni omjer između najniže i najviše zarade, od $1: 1$ do $1: 2$, ili relativno visok poželjni omjer između najniže i najviše zarade, od 1:4 naviše. Pokazalo se da razvrstavanje ispitanika prema tome kakav raspon zarada preferiraju nije povezano $\mathrm{s}$ aspiracijom za višim dohotkom, te autori nisu mogli potvrditi hipotezu da je društvena norma egalitarnosti glavna odrednica razine aspiracija. Usprkos tom nalazu, Županov je ustrajao na toj tezi u svim svojim kasnijim radovima (Dolenec, 2014).

Tadić i Županov (1969) propuštaju komentirati jedan važan nalaz svoje ankete: najveće aspiracije za povećanjem dohotka pokazuju oni s najmanjim dohotkom. Autori većinu analize posvećuju razlikama u apsolutnim iznosima dinara u kojima su ispitanici navodili željeno povećanje dohotka, gdje dobivaju nalaz da ne postoji povezanost s osobnim aspiracijama za povećanjem dohotka. No, ako umjesto apsolutnih iznosa analiziramo relativne razlike između nominalnog i željenog dohotka, dakle u postotku, pojavljuje se vrlo čvrsta povezanost: ispitanici s najnižim dohotkom aspiriraju za povećanjem od 94 posto, dok oni s najvišim dohotkom aspiriraju za povećanjem od 23 posto. Jednak se nalaz ponavlja i kada se ispitanici razvrstaju prema radnim kvalifikacijama: oni s najnižim kvalifikacijama teže za povećanjem zarade od 64 posto, dok rukovodioci aspiriraju za povećanjem od 36 posto. Dakle, dok Tadić i Županov (ibid.: 68) tvrde da radikalni egalitarizam "plafonira ne samo dohotke nego i ekonomske aspiracije pojedinca", njihovi nalazi pokazuju suprotno: najniže plaćeni radnici imaju najviše aspiracije za povećanjem dohotka. Stoga, ako industrijalizam, kako kaže Županov (ibid.), "pretpostavlja neprekidan porast aspiracija kao glavnu pokretačku snagu ekonomskog sistema", čini se da ipak ne možemo radnike okriviti za onemogućavanje razvoja. Ovo je još jedna ilustracija

15 Istraživanje je provedeno 1966. godine "u 10 odabranih industrijskih poduzeća u jednom industrijskom centru u Hrvatskoj", a anketu je "pod rukovodstvom J. Županova provela grupa sastavljena od suradnika Ekonomskog instituta u Zagrebu (Darinka Tadić, Grozdana Pažameta, Božo Jušić), suradnika Ekonomskog instituta u Osijeku (Barbara Medanić) i grupe industrijskih psihologa iz dotičnog industrijskog centra” (1969: 281). 
načina na koji Županov ispušta iz analize aspekte svojih nalaza koji ne idu u prilog njegovoj tezi.

Krajem šezdesetih godina kada je Županov provodio ta istraživanja, rasprave o distribuciji dohotka bile su vrlo aktualne u medijima. Dnevne novine Borba u travnju 1969. objavile su rezultate istraživanja o percepcijama industrijskih radnika u Sloveniji koje su bile povezane s opravdanim visinama i rasponima dohodaka, kao i o njihovim stavovima prema neopravdanom bogaćenju. Glavni je nalaz tog istraživanja da ispitanici smatraju kako u društvu bogaćenje nije proširena pojava, nego da je većinom riječ o posljedici izigravanja propisa i špekulantskog rada. Nadalje, ispitanici su smatrali da se neopravdano bogate obrtnici i drugi privatnici te osobe na rukovodećim pozicijama koji imaju prilike doći do dodatnih poslova. Nekoliko mjeseci nakon toga Milan Bajec u Borbi je objavio tekst "Opsesija o privatniku", ${ }^{16}$ što je sintagma koju je Županov preuzeo i ugradio u svoj egalitarni sindrom. U to su vrijeme artikulirani zahtjevi da se oslobodi veći prostor za privatni sektor, i Bajec zagovara tu poziciju u svom tekstu spominjući "prirodnu averziju koju u javnosti izaziva bogaćenje pojedinih zanatlija". ${ }^{17}$

Rasprava o poželjnom rasponu dohotka, koja se vodila krajem šezdesetih godina u Jugoslaviji, danas je ponovno aktualna. Tema opravdane nejednakosti povezana je s temeljnim legitimacijskim narativom u kapitalizmu, a prema kojemu svatko stječe dohodak svojim radom, odnosno svojom produktivnom poduzetničkom aktivnošću. Dohodovnu nejednakost opravdava to što je ona rezultat toga meritokratskog principa (Grdešić, 2016). U teorijskom smislu riječ je o metodološkom individualizmu koji zaklanja sustavne prepreke u pristupu i ostvarivanju prava, od obrazovanja nadalje. Takav način rasuđivanja, prema kojem onaj tko radi više, tko je više učio, tko je inovativan i produktivan zaslužuje više, nesumnjivo čini dio zdravorazumskog rasuđivanja kojim objašnjavamo društvene ishode. No, čak i tako reducirana individualistička perspektiva neizostavno sadržava ideju pravednosti, pitanje o tome što je pošteno, kolike su razlike opravdane $\mathrm{i}$ - vjerojatno najvažnije - pitanje izvora tih razlika: jesu li razlike u prihodima zaslužene ili nezaslužene?

O aktualnosti takvih rasprava svjedoči, na primjer, činjenica da su Švicarci između proljeća 2013. i ljeta 2016. tri puta na saveznim referendumima glasovali o pitanjima raspodjele dohotka. U ožujku 2013. prihvatili su prijedlog građanske ini-

16 Tekst je osvrt na sjednice Vijeća naroda i Privrednog vijeća Savezne skupštine na kojima se raspravljalo o pravnim ograničenjima privatne inicijative. Konkretno se razmatrala odredba koja je tada bila na snazi, a koja je u privatnom sektoru ograničavala vlasništvo do razine petotonskog kamiona, vozila s pet sjedala te tri zaposlena.

17 “Opsesija o poduzetniku”, Milan Bajec, Borba, 6. srpnja 1969. 
cijative koja je bila naslovljena "Protiv otimačine", a koja je tražila da se ograniči visina naknada za izvršne direktore korporacija. ${ }^{18} \mathrm{U}$ jesen iste godine odbacili su inicijativu " $1: 12$ " koja je tražila da se raspon plaća u poduzećima ograniči na navedeni omjer. ${ }^{19}$ Slogan te kampanje bio je "mjesečna plaća direktora ne može biti veća od godišnje plaće radnika”. U ljeto 2016. Švicarci su pak odbacili prijedlog da se uvede opći zajamčeni dohodak. ${ }^{20}$

Svaku od tih kampanja trebalo bi pomno analizirati kako bismo dobili jasniju sliku o njihovim ishodima. No, one nesumnjivo odražavaju činjenicu da se danas u srcu kapitalističke Europe, gdje je nemoguće govoriti o ostacima socijalističkog mentaliteta, u javnosti raspravlja i kolektivno odlučuje o pitanjima distribucije dohodaka, odnosno o tome što je poštena naknada te o tome kolika je nejednakost u društvu opravdana ili poželjna. Jednu dimenziju rasprave o dohodovnim nejednakostima koja je posebno bitna za TES čini pitanje zasluženosti odnosno opravdanosti razlika. Dok u klasičnoj ekonomskoj teoriji osobno zadovoljstvo (utility) pojedinca ne ovisi o ponašanju drugih, sociolozi već dugo tvrde da nejednakost osjećamo kao nepravdu ponajprije mjereći se u odnosu prema nama referentnim grupama (tzv. teorija relativne deprivacije). Clark i D'Ambrosio (2014) dali su obuhvatan pregled novijih istraživanja koja potvrđuju da je zadovoljstvo vlastitim prihodima doista $u$ velikoj mjeri određeno usporedbom s referentnom grupom. $\mathrm{Ne}$ samo da prihodi drugih značajno utječu na naše zadovoljstvo vlastitim prihodima nego izvor tih prihoda predstavlja ključan faktor naše procjene o tome što je opravdano. Ljudi ponajprije negativno reagiraju na nejednakost prihoda ako smatraju da su oni nezasluženi (ibid.).

Primijenimo li te uvide na Hrvatsku, u kojoj je tranzicijsko razdoblje devedesetih karakterizirano kao, da se poslužimo izrazom Terrya Eagletona, "pljačka usred bijela dana" (2011), široko prisutan stav o dohodovnim nejednakostima kao nezasluženima vjerojatno je očekivan. U svom ranijem istraživanju Štulhofer (2000) navodi kako se 1998. godine 67\% ispitanika slagalo da je krajnji učinak privatizacije produbljivanje jaza između bogatih i siromašnih, a čak $86 \%$ je smatralo da je u Hrvatskoj nekoliko obitelji na sumnjiv način stvorilo poslovna carstva. U mjeri u

18 Detaljnije informacije o toj inicijativi dostupne su na službenim stranicama Švicarske konfederacije: https://www.bk.admin.ch/ch/d/pore/va/20130303/index.html. Zadnji put pristupljeno 14. kolovoza 2018.

19 Detaljnije informacije o toj inicijativi dostupne su na službenim stranicama Švicarske konfederacije: https://www.bk.admin.ch/ch/d/pore/va/20131124/index.html. Zadnji put pristupljeno 14. kolovoza 2018.

${ }^{20}$ Detaljnije informacije o toj inicijativi dostupne su na službenim stranicama Švicarske konfederacije: https://www.bk.admin.ch/ch/d/pore/va/20160605/index.html. Zadnji put pristupljeno 14. kolovoza 2018. 
kojoj očekujemo da su se takve percepcije zadržale, uvriježeni stav o nezasluženim razlikama možda pomaže objasniti raširen društveni otpor rastu nejednakosti.

Bez obzira na eventualno slaganje ili neslaganje o mogućim uzrocima tog otpora, nakon novih radova Štulhofera, Burića i suradnika još uvijek ostaje otvoreno pitanje je li egalitarizam u Hrvatskoj previsok te, ako jest, u odnosu prema čemu. Ako su, na primjer, egalitarne aspiracije povezane s dohotkom jednako visoke $\mathrm{u}$ Švicarskoj ili Njemačkoj, na koji način to mijenja našu raspravu o ulozi socijalističkog naslijeđa u tom fenomenu? Nadalje, ako smo, globalno gledano, prosječno egalitarni, kako onda upravo Hrvatsku prisutnost egalitarizma koči, a druge zemlje ne? Da bismo pokušale adresirati ta pitanja, posežemo za empirijskim mjerama dohodovne egalitarnosti. Schneider (2012) je, koristeći se podacima iz anketnog istraživanja ISSP-a iz 2006. godine, razvila mjeru individualne percepcije pravednosti u distribuciji dohotka. Oslanjajući se na procjene ispitanika o stvarnoj visini plaće direktora i plaće nekvalificiranog radnika te procjene poželjne visine plaće direktora i plaće nekvalificiranog radnika, ona izvodi mjeru legitimnosti dohodovne nejednakosti (LDI) u društvu:

$$
\text { LDI }=\ln \left[\left(\text { Percipirana }_{\text {direktor }} / \text { Percipirana }_{\text {radnik }}\right) /\left(\text { Poželjna }_{\text {direktor }} / \text { Poželjna }_{\text {radnik }}\right)\right]
$$

Mi ponavljamo njezin postupak koristeći podatke iz ISSP-a 2009. ${ }^{21}$ Grafikon 1. prikazuje rezultate za sve zemlje uključene u istraživanje, s izdvojenim vrijednostima prosjeka i vrijednostima za Hrvatsku.

Ako ispitanici smatraju da su u zemlji u kojoj žive stvarne razlike između dohodaka direktora i radnika te poželjne razlike između njihovih dohodaka jednake, vrijednost na grafikonu je nula (0). Da ispitanici smatraju kako bi poželjna nejednakost trebala biti veća, to bi bilo izraženo negativnim vrijednostima na grafikonu, no nijedna zemlja ne pokazuje takve nalaze. U svim zemljama uključenima u istraživanje postoji diskrepancija između stvarnih i poželjnih dohodovnih nejednakosti. Drugim riječima, dominacija stava da bi dohodovne razlike trebale biti manje nego što jesu je za većinu razvijenih društava normalno stanje.

Nadalje, Grafikon 1. pokazuje da se Hrvatska nalazi na samom prosjeku zemalja uključenih u analizu. Drugim riječima, ako sasvim doslovno primijenimo Županovljev empirijski test o aspiracijama za dohotkom kao ključnom odrednicom homo economicusa koji pokreće društveni razvoj, te zatim usporedimo stanovnike Hrvatske sa stanovnicima niza drugih zemalja, vidimo da smo prosječno egalitarno orijentirani. Na primjer, stanovnici Njemačke, Francuske i Švicarske, prema ovome

${ }^{21}$ ISSP Research Group (2017): International Social Survey Programme: Social Inequality IV ISSP 2009. GESIS Data Archive, Cologne. ZA5400 Data file Version 4.0.0, doi:10.4232/1.12777. Hrvatska ( $=1201)$, terensko istraživanje od 1. lipnja do 15. rujna 2009, proveo Institut za društvena istraživanja u Zagrebu. 
Grafikon 1. Odnos percipirane i pravedne dohodovne nejednakosti između dohotka direktora i radnika

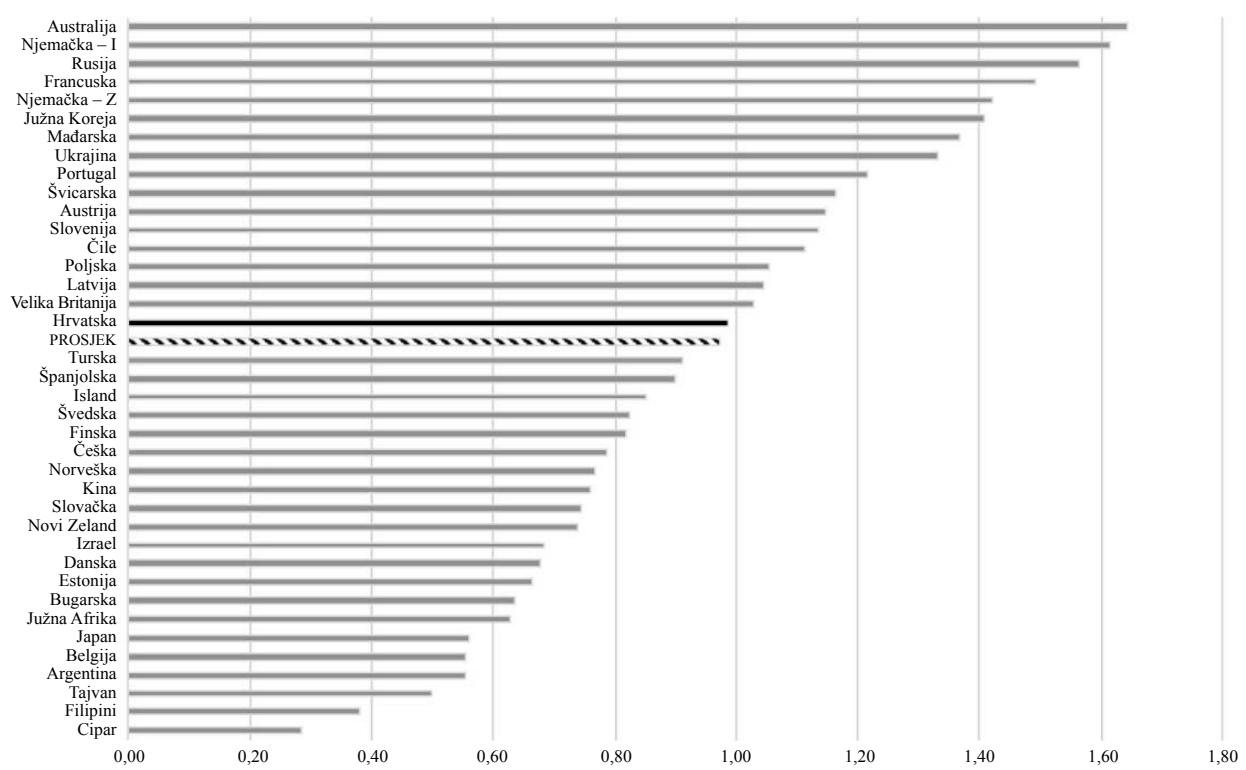

Izvor: International Social Survey Programme. Modul “Social Inequality IV - ISSP 2009”.

mjerenju, više teže uravnilovci nego stanovnici Hrvatske. Što to govori o tezama, koje zastupaju Štulhofer, Burić i suradnici, da je zahtjev za smanjenjem dohodovne nejednakosti atavizam socijalističke prošlosti te da prisutnost takvog zahtjeva koči društveni razvoj? Možemo li kao društveni znanstvenici i dalje tvrditi da je uravnilovka glavni problem koji koči razvoj hrvatskog društva?

I dalje će neki reći da sve te identificirane slabosti ne znače da egalitarni sindrom "ne postoji”. Na kraju krajeva, budući da su Štulhofer i Burić (2015, 2016) svom zadatku pristupili strogo empiricistički, zanemarujući brojna teorijska i metodološka pitanja, ostaje nam analizirati kako su pristupili izboru dizajna svog istraživanja, konceptualizaciji, operacionalizaciji te testiranju TES-a.

\section{Goli empiricizam}

Prema Štulhoferu i Buriću (2015), Dolenec (2014) griješi kada tretira TES kao empirijsku teoriju. Autori se slažu s Lalićem (2005: 144) da Županovljeva teorija nije "provizorni gotovi proizvod i cjeloviti konceptualni okvir". No, nakon te konstatacije pristupaju empirijskom testiranju kao da TES jest gotov koncept i cjelovit 
konceptualni okvir. Svode svoj zadatak na operacionalizaciju, mjerenje i statističke testove, odnosno obavljanje "nedovršenog posla" hrvatske sociologije (Štulhofer i Burić, 2015: 12), budući da, kako kažu, "tijekom velikog dijela životnog vijeka teorije egalitarnog sindroma (TES-a) domaće društvene znanosti jednostavno nisu posjedovale dovoljnu razinu metodološke sofisticiranosti za sustavnu empirijsku validaciju teorije" (ibid.: 11). ${ }^{22}$

Suhi prikaz statističkih postupaka kojima se služe Štulhofer i Burić (2015, 2016) dobro ilustrira Bourdieuov opis problema golog empiricizma, koji kaže da je takav tehnički formalizam izlaganja nalaza "bliži logici magičnih rituala nego rigorozne znanosti" (1988: 774). Iako na površini proizvodi dojam rigoroznosti, takav formalizam zapravo zaklanja kritički pristup TES-u. Osim toga, formalizam služi stvaranju dojma neutralnosti, na čiju je problematičnost u kontekstu rasprave o egalitarnom sindromu upozorila Doolan (2016).

Polazeći od pretpostavke da je TES neupitno razrađen za empirijsku analizu, autori preskaču niz važnih koraka u dizajnu empirijskog istraživanja. Osim što je izostala integracija propozicija TES-a u suvremenim istraživanjima u modernizacijskoj teoriji, što ozbiljno narušava njegov status, Štulhofer i Burić $(2015,2016)$ također ne raspravljaju o izboru primjerenih metoda istraživanja, kao ni o tome što se izborom metode anketnog upitnika dobiva ili gubi. Na razini unutarnje valjanosti koncepta preskaču raspravu o tome jesu li sve dimenzije jednako važne, koja je razina njihove međusobne povezanosti i mogućih preklapanja te, s obzirom na to, kako bi trebalo specificirati hipoteze o njihovom izdvojenom, a onda i skupnom utjecaju na društveni razvoj. Nadalje, iako autori kao ograničenje vlastite analize navode "određenu arbitrarnost postupka" generiranja čestica, budući da je "u cijelosti ovisna o načinu na koji su dvojica autora iščitavali Županovljev teorijski rad" (Štulhofer i Burić, 2015: 27), tim postupkom stvaraju rizike koji imaju fundamentalne reperkusije na njihovu analizu. Pojednostavnjeno, ako uključene čestice ne mjere ono što autori tvrde da mjere, onda ni nalazi ne znače ono što autori tvrde da znače. Na kraju, u svojim analizama koje temelje na rezultatima anketnih istraživanja Štulhofer i suradnici ne vode dovoljno računa o ograničenjima svojih podataka. U nastavku adresiramo svaku od tih identificiranih slabosti.

${ }^{22}$ Ako ostavimo po strani preuzetnost takvog samopozicioniranja, ta kvalifikacija jednostavno nije točna. Empirijska istraživanja vrijednosnih orijentacija temeljena na anketnim upitnicima u Hrvatskoj, odnosno u Jugoslaviji rađena su od sedamdesetih godina prošlog stoljeća. Tako, na primjer, zagrebački Institut za društvena istraživanja od 1984. godine provodi anketna istraživanja društvene strukture (Hodžić i Krištofić, 2014), a beogradski Institut društvenih nauka još je 1977. objavio istraživanje društvenih vrijednosti koje uključuje i faktorsku analizu vrijednosnih klastera pojedinih društvenih slojeva (Popović i dr., 1977). 


\section{Odabir metode istraživanja}

Prije odluka koje se tiču operacionalizacije nužno je temeljem karakteristika teorije donijeti odluku o izboru metoda istraživanja. Županov u tekstovima s kraja šezdesetih inicijalno raspravlja o važnosti radikalnog egalitarizma kao prepreci razvoju, da bi nakon toga tu tezu razvio u TES. TES predstavlja složeniji konstrukt u kojemu, osim radikalnog egalitarizma, važnu ulogu imaju negativni stavovi prema poduzetništvu i statusu ekspertize. Razmatrajući otpor "neopravdanom bogaćenju”, Županov (1987a) tvrdi da taj stav "posebno dolazi do izražaja u odnosu na neke posebne vrste privatnika kao što su visoke intelektualne profesije (profesori, liječnici, umjetnici i sl.), kao i na zabavljačke zvijezde (nogometaši, popularni pjevači i sl.)" (ibid.: 52). Isto tako, kad objašnjava zašto je opsesija o privatniku i bogaćenju štetna za razvoj, govori o tercijarnom sektoru u kojem "osobni rad i inicijativa ima bitnu ulogu" (ibid.: 69). Stoga je razumljivo zašto se tri komponente egalitarnog sindroma direktno odnose na osporavanje statusa stručnjaka: antiprofesionalizam, intelektualna uravnilovka i antiintelektualizam (s tim da se intelektualna uravnilovka sastoji od antipoduzetništva, antiinovatorstva i antikreativnosti). Te dimenzije povezuje autorova percepcija društva koje ne cijeni svoju intelektualnu elitu. ${ }^{23}$

Umjesto da ekspertiza bude i simbolički i materijalno valorizirana, Županov je smatrao da je u Jugoslaviji na snazi truli kompromis između nekompetentne političke elite i egalitarnog radništva, odnosno "koalicija nejednakih" u kojoj su radnici prihvatili službenu ideologiju, a elita je prihvatila vrijednosni kôd radikalnog egalitarizma (1987a). Županov je tako u razvoju teze od radikalnog egalitarizma do egalitarnog sindroma temelj kritike premjestio na problem političke podobnosti i tzv. klikaštva koji presudno utječe na društveni razvoj Jugoslavije - o čemu su u to vrijeme pisali Rus (1966), Horvat (1969) i drugi. U raspravi koju je 1984. organizirao časopis Ekonomika (1987b) Županov uspoređuje taj, kako ga on vidi, klijentelistički odnos između fizičkog radništva i političke klase u Jugoslaviji sa situacijom u SAD-u gdje, kako on smatra, društvo oblikuje koalicija između vlasnika kapitala i znanosti. Citira podatke Dragomira Pantića iz 1974. za Jugoslaviju prema kojima su društvene grupe s najviše izraženim egalitarnim orijentacijama umirovljenici, kućanice i radnici. Županov tumači da "kad su ljudi u takvom socioekonomskom položaju koji ne daje mogućnosti da se putem nekog mehanizma ekonomskog takmičenja izdignu u prvi plan, imate ovakvu orijentaciju. I ovakva je orijentacija kod njih način da se sačuva ljudsko dostojanstvo" (ibid.: 90). On, dakle, ne osporava racionalnost egalitarnih stavova kod većine, nego ne misli da bi njihove vrijednosti

23 Nota bene, takav je stav teško obranjiv u svjetlu nedavno objavljenih podataka prema kojima su 1975. godine u Jugoslaviji sveučilišni profesori činili najbrojniju skupinu unutar elita čiji dohodci pripadaju u 0,1\% distribucije (Novokmet, 2017: 292). 
trebale biti društveno mjerodavne (što mnogo govori o njegovom viđenju demokracije, ali to je zasebna tema). Za njega, uspješan razvoj traži da društvo oblikuje ekonomska elita uz pomoć znanosti. Županov govori o stručnjacima i znanstvenicima kao skupinama koje su ravnopravno uključene u sustav dominacije, a činjenicu da vlasničke klase "u nauci i u tehnici traže svoj legitimitet" vidi kao veliku šansu za razvoj znanosti (ibid.: 95).

Bez obzira na to slažemo li se s tim tezama, ako smatramo da Županov kao glavni problem razvoja jugoslavenskog društva vidi političku "koaliciju nejednakih" između nekompetentne političke elite i egalitarnih radnika, da bismo ovim tezama dali empirijsku potkrepu, potrebne su nam analize dinamike među elitama, studije razvoja ekonomskih i političkih institucija, analize političkih rascjepa i dinamike izbornog natjecanja u Hrvatskoj. Anketnim upitnikom kao jedinom metodom istraživanja TES se ne može empirijski potvrditi. Može se samo, uz uvjet da je mjerni instrument valjan, utvrditi prisutnost određenih vrijednosti u populaciji i tako zahvatiti jedan njezin aspekt.

\section{Problemi konceptualizacije i operacionalizacije}

U prvom istraživanju autori usputno, u bilješci, navode da se egalitarizam obično tretira kao jednodimenzionalan konstrukt (Štulhofer i Burić, 2015: 10), dok se u drugom, također u bilješci, ukratko osvrću na pluralizam koncepcija egalitarnosti (Burić i Štulhofer, 2016: 4). Takav pristup Županovljevoj teoriji, koju sami autori opisuju kao labav teorijski okvir, neizbježno ih vodi do paradoksa konceptualizacije (Kaplan, 1964, prema: Adcock i Collier, 2001). Kako se taj paradoks manifestira? Dobra konceptualizacija treba pojasniti semantičko polje fenomena i postaviti nosive elemente operacionalizacije koji vode istraživača u odabiru empirijskih koraka analize (Sartori, 1984; Adcock i Collier, 2001). Osnovni pristup procjeni kvalitete empirijskih istraživanja te vrste, takozvana procjena valjanosti mjernih instrumenata i-ili modela, usporedba je mjernih alata s "idejom" teorijskih konstrukata koji bi trebali suštinski zahvatiti bit istraživanog fenomena (Adcock i Collier, 2001: 530). Logika je jednostavna: ako teorijski konstrukt nije dobro definiran (konceptualiziran), ne postoji ni referentna točka na temelju koje možemo odrediti u kojoj je mjeri njegova empirijska razrada u indikatore uspješna (operacionalizacija). Drugim riječima, ako ne možemo povezati sadržajnu valjanost čestica i iz njih kreiranih kompozitnih indikatora s pozadinskim konstruktom - u ovom slučaju s egalitarnim sindromom - onda je evaluacija rezultata statističkih analiza Sizifov posao. U tom smislu je konceptualizacija od fundamentalne važnosti ne samo za istraživače koji provode analizu nego i za sve koji žele istraživanje replicirati ili na njemu na neki drugi način graditi svoja istraživanja.

Prva teškoća s kojom se Štulhofer i Burić (2015) susreću jest Županovljeva karakterizacija egalitarnog sindroma ne samo kao višedimenzionalne kulturne vri- 
Slika 1. Ilustracija Županovljeve konceptualizacije egalitarnog sindroma kao višedimenzionalnog i višerazinskog konstrukta

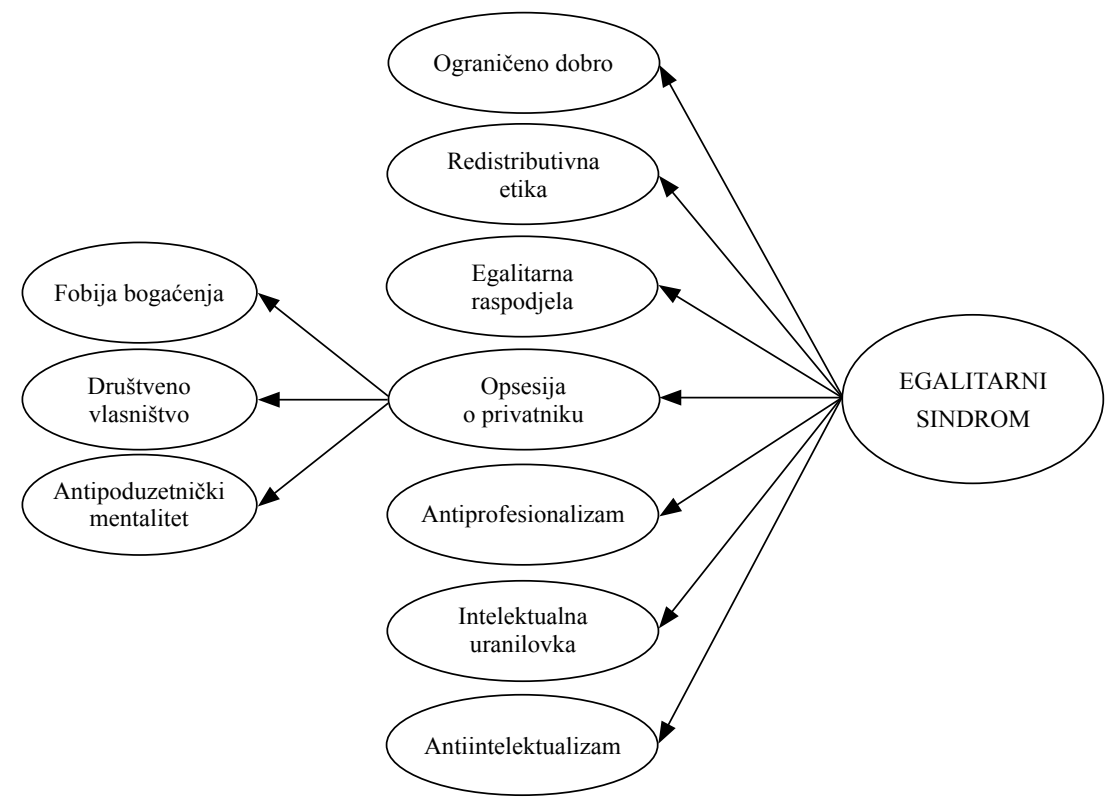

jednosti nego i kao konstrukta višeg reda, odnosno latentne dimenzije treće razine (vidi Sliku 1). Tako postavljena struktura egalitarnog sindroma nužno veže niz teorijskih, a ne samo empirijskih pretpostavki o vrsti međusobne povezanosti elementarnih komponenti egalitarnog sindroma i njihovoj vezi s dimenzijom višeg reda (vidi Johnson i dr., 2012). Dva su osnovna oblika latentnog konstrukta višeg reda: nadređeni (eng. superordinate) konstrukt i skupni (eng. aggregate) konstrukt (Bollen i Lennox, 1991; Law, Wong i Mobley, 1998; Johnson i dr., 2012). Ako smatramo egalitarni sindrom latentnom dimenzijom višeg reda u kojoj su pojedine dimenzije manifestacije TES-a, onda trebamo testirati nadređeni konstrukt. No, ako je TES manifestacija kombinacije nižih latentnih dimenzija, onda je riječ o skupnom konstruktu. To razlikovanje implicira i unaprijed teorijski razmotrene odnose među dimenzijama i odabir statističke analize (Johnson i dr., 2012). U prvom slučaju, visoka razina povezanosti među dimenzijama niže razine očekivana je i poželjna. Izbacivanje jedne ili dviju dimenzija iz modela ne bi trebalo promijeniti značenje latentne dimenzije višeg reda. U drugom slučaju, dimenzije moraju biti sadržajno neovisne i nepovezane jer je skupni konstrukt određen ne samo zajednič- 
kom varijancom svojih dimenzija nego i varijancom specifičnom za svaku dimenziju pojedinačno (ibid.). Iz istraživanja koje su proveli Štulhofer i Burić saznajemo samo da egalitarni sindrom obuhvaća "sedam različitih manifestacija egalitarnih stavova, vrijednosti ili perspektiva" (Burić i Štulhofer, 2016: 2). Pretpostavljamo da su ga odlučili tretirati kao nadređeni konstrukt jer koriste model konfirmatorne faktorske analize prikazan na Slici 1, ali detaljniju raspravu o svojoj odluci autori ne nude.

Teškoće povezane s višedimenzionalnošću sindroma najvidljivije su u interpretaciji analize distinktnosti latentnih dimenzija. Autori navode da analiza mora pokazati "razmjerno nisku povezanost među latentnim konstruktima" (2015: 22), ali potom izvještavaju da je povezanost dviju od pet dimenzija u revidiranom modelu skale egalitarnog sindroma - SEMA- $15,{ }^{24}$ egalitarne raspodjele i opsesije o privatniku, vrlo visoka $(0,81) .{ }^{25}$ Ako je povezanost dimenzije "egalitarne raspodjele" $i$ “opsesije o privatniku" visoka, na što korelacijski koeficijenti jasno ukazuju, dva su moguća objašnjenja. Prvo, da se te dvije dimenzije ne mogu tretirati kao odvojene i distinktne komponente, nego su potencijalno sadržajno redundantne te, drugo, da je njihova operacionalizacija kroz čestice neuspješna i možda zahvaća neki "treći" fenomen. Zasićenja čestica i latentnih dimenzija često mogu biti rezultat nekih "trećih" egzogenih čimbenika koje istraživači nisu uzeli u obzir, a koji mogu umjetno "napuhati” zajedničku varijancu indikatora do te mjere da se povezanost među dimenzijama interpretira kao postojanje neke više latentne dimenzije (Johnson i dr., 2012). Burić i Štulhofer (2016) kasnije spominju mogućnost povezanosti prihvaćanja egalitarnog sindroma i korupcije ili kršenja normi, ali ne uzimaju u obzir kako je moguće da njihove čestice zapravo zahvaćaju te fenomene, a ne latentnu dimenziju egalitarnog sindroma.

Rasprava o dimenzionalnosti egalitarnog sindroma i povezanosti dimenzija nužna je i zbog eksplanatorne moći konstrukta egalitarnog sindroma i mjernih instrumenata. Konceptualizacija višedimenzionalnog konstrukta uključuje i razmišljanje o praktičnoj primjeni mjera SEMA-27 i SEMA-15. Kako ćemo i gdje ćemo povući granice između latentnih dimenzija koje su komponente sindroma i onih koje mogu biti povezane sa sindromom, ali nisu njegova manifestacija nego potencijalna egzogena objašnjenja? Nadalje, kako ćemo analizirati odnos između prihvaćanja egalitarnih vrijednosti i stavova prema institucijama tržišta, što Burić i Štulhofer (2016) sami sugeriraju kao jedan od budućih istraživačkih smjerova, ako uključene čestice već zahvaćaju odnos ispitanika prema tržištu?

${ }^{24}$ Autori testiraju dužu (27 čestica - SEMA-27) i kraću (15 čestica - SEMA-15) verziju skale egalitarnog sindroma (SEMA).

${ }^{25}$ Autori propuštaju navesti razinu povezanosti među latentnim dimenzijama u analizi iz 2016. u kojoj testiraju TES na nacionalno reprezentativnom uzorku. 
Slični problemi vidljivi su i u operacionalizaciji, odnosno odabiru čestica. Iako autori transparentno opisuju postupak kreiranja anketnih pitanja, neke su njihove odluke nelogične. Prvo, iako je praksa u završnome mjernom instrumentu (SEMA-27 i SEMA-15) da se koriste one čestice koje su visoko saturirane $(<0,40)$ i nisu sadržajno redundantne, odabir samo čestica s visokom razinom saturacije kako bi homogenizirali konstrukt može naškoditi valjanosti konstrukta. Ilustrativan su primjer čestice odabrane za dimenziju "ograničenog dobra". Perspektivu ograničenog dobra Županov ilustrira stavom prema kojemu "ako jednom ne omrkne, drugom ne svane" (1987a: 47). Drugim riječima, unutar te perspektive smatra se da svako poboljšanje statusa jednog člana zajednice ide nauštrb drugoga, pa se preferira redistribucija.

Latentnu dimenziju ograničenog dobra (SEMA-27 i SEMA-15) autori mjere sljedećim česticama:

- Država treba zakonski spriječiti da neki ljudi ili skupine budu uspješniji od drugih.

- Država treba donijeti zakone koji će onemogućiti da nekim društvenim skupinama standard raste brže nego svima ostalima.

- Država bi trebala intervenirati kad god se neki pojedinci ili grupe bogate brže od drugih.

Istovremeno je pitanje "Rast standarda nekog pojedinca ili grupe u nekom društvu uvijek ide nauštrb drugih pojedinaca i grupa", za koje se čini da sadržajno najbolje zahvaća inicijalnu Županovljevu ideju, isključeno iz daljnje analize zbog niske saturacije. Takve su odluke opasne zato što se može upasti u zamku "obrnute operacionalizacije" kada mjernim instrumentima umjetno pridodajemo značenja iz polaznog konstrukta (Corbetta, 2003).

Analiza višedimenzionalnih latentnih konstrukata nije strana društvenim znanostima. No, iako autori navode da je temeljni mjerni model koji predlažu jednostavan (Štulhofer i Burić, 2015: 17), konfirmacijska faktorska analiza s tri razine latentnih dimenzija u društvenim je znanostima rijetka (Rudnev i dr., 2018). Osim toga, konfirmatorni modeli usmjereni na testiranje kompleksnih odnosa, poput modela koji predstavljaju Burić i Štulhofer $(2015,2016)$, uvijek se grade inkrementalno. Prvo se testira pristajanje modela za svaku zasebnu dimenziju prvog reda, potom drugog reda i, na kraju, ako se teorijski očekuje visoka razina povezanosti dimenzija drugog reda, testira se model s latentnom dimenzijom trećeg reda. Samo ako konstrukt višeg reda ima veću eksplanatornu snagu od njegovih zasebnih dimenzija odnosno, pojednostavnjeno, ako su istraživači pokazali da novi koncept donosi više od pukog zbroja svojih komponenata, prihvaća se kompleksniji višerazinski model. Burić i Štulhofer $(2015,2016)$ ne uzimaju to u obzir, nego testiraju kompleksniji model bez usporedbe tog modela sa strukturom u kojoj se Županovljeve dimenzije, pa i egalitarni sindrom, manifestiraju direktno iz čestica. 
Utjecaj kompleksnosti modela koji autori odabiru na odluke o vrstama analize i interpretaciju pristajanja skala vidljiv je i kod testiranja invarijantnosti. Iako Burić i Štulhofer (2016) provode test invarijantnosti kod populacijskog uzorka, za kompleksne modele s latentnim dimenzijama na više razina njihova analiza je neprikladna (Rudnev i dr., 2018) jer ne uzima u obzir kompleksnost postavljenog modela. Zato smo odlučili provesti novu analizu invarijantnosti modela SEMA-15 u kojoj je ona testirana inkrementalno, za svaku razinu mjernog i strukturnog dijela modela, te cjelovito, testirajući sve tri razine na kojima se invarijantnost mora potvrditi prije korištenja skala: konfiguracijske, mjerne i skalarne. Prema našoj analizi, koja je u potpunosti prikazana u Prilogu 1, model egalitarnog sindroma ne zadovoljava uvjete konfiguracijske invarijantnosti među dobnim skupinama te se toga ne može koristiti za testiranje hipoteza.

\section{Testiranje hipoteze o mogućim posljedicama kulturne inercije}

Burić i Štulhofer (2016: 15) korelacijskom analizom testiraju odnos između prihvaćanja egalitarnog sindroma i indikatora socijalno-ekonomskog razvoja po županijama kako bi ispitali središnju Županovljevu tezu o "egalitarnom sindromu kao sociokulturnoj kočnici razvoja". Na temelju bivarijantnih korelacijskih analiza indikatora županijskog razvoja i prosječne vrijednosti SEMA-27 po županijama autori zaključuju da postoji sustavna negativna povezanost između prihvaćanja egalitarnih vrijednosti i indikatora socijalno-ekonomskog razvoja. Budući da se u kasnijim radovima (Vuković, Štulhofer i Burić, 2017; Rimac, Burić i Štulhofer, 2017) autori koriste istim anketnim podacima na razini 21 županije te ističu taj nalaz kao potporu Županovljevoj tezi o podrijetlu i perzistenciji TES-a, važno je upozoriti na metodološke slabosti te analize koje dovode u pitanje njezinu pouzdanost.

Ponajprije, nacionalni uzorak anketnog istraživanja, kako Burić i Štulhofer (2016) sami ističu, nije bio pripremljen kako bi se statistički testirale hipoteze na županijskoj razini i reprezentativan je samo na razini države. Odatle, nadalje, proizlazi da je uzorak od tisuću ispitanika nedostatan za takvu analizu. Naime, u nekim županijama prosječnu vrijednost SEMA-27 autori računaju na temelju odgovora vrlo malog broja ispitanika. Na primjer, o stavovima u Ličko-senjskoj županiji zaključuju na temelju odgovora osam ispitanika, a o onima u Šibensko-kninskoj županiji na temelju odgovora 20 ispitanika. Usto su sve analize provedene na samo 21 slučaju, na razini županija, što značajno utječe na snagu statističkih testova i pouzdanost rezultata koje autori predstavljaju.

Zašto su analize koje proizlaze iz takvih podataka nepouzdane? Uzmimo jedan primjer. Prema nalazima koje predstavljaju Burić i Štulhofer (2016), prosječna vrijednost aditivne skale SEMA-27 u Požeško-slavonskoj županiji iznosila je 3,65 (na skali od 1 do 5). No, 3,65 predstavlja samo procjenu aritmetičke sredine, 
Grafikon 2. Prosjek prihvaćanja egalitarnog sindroma (SEMA-27) po županijama s 95-postotnim granicama pouzdanosti

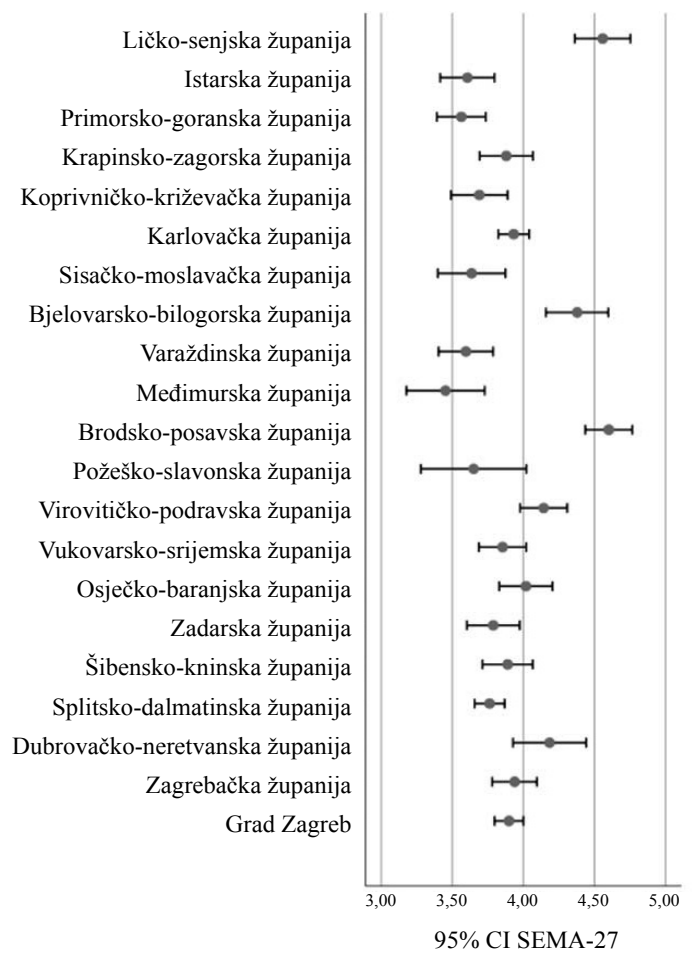

Izvor: Podaci iz nacionalnoga probabilističkog uzorka od 1000 ispitanika provedenog 2016. (Burić i Štulhofer, 2016).

koja zbog varijabilnosti statističkih uzoraka uvijek nosi/sadržava određenu razinu pogreške. Pogreška je veća što je manji broj ispitanika čije odgovore koristimo za izračun prosjeka. Međutim, statističke analize omogućavaju da, uz određenu razinu vjerojatnosti (najčešće se uzima vjerojatnost od 95 posto), procijenimo raspon prosječnih vrijednosti koje bi trebale obuhvatiti stvarnu razinu prihvaćanja SEMA-27 u populaciji Požeško-slavonske županije. U slučaju Požeško-slavonske županije taj raspon se kreće od 3,3 do 4,2. Drugim riječima, jednako je vjerojatno da je prosječna vrijednost SEMA-27 u Požeško-slavonskoj županiji bilo koja vrijednost unutar toga procijenjenog intervala.

Što to znači za analizu koju su proveli autori? Grafikon 2. prikazuje prosjek prihvaćanja egalitarnog sindroma (SEMA-27) po županijama uz odgovarajuće 
95-postotne granice pouzdanosti. U većini županija, zbog malog broja ispitanika koji čine uzorke unutar županija, rasponi su granica veliki i vrijednosti se preklapaju. Drugim riječima, ako u obzir uzmemo te raspone prosječnih vrijednosti, ne možemo nedvojbeno utvrditi da je prihvaćanje egalitarnih vrijednosti snažnije u Karlovačkoj nego u Sisačko-moslavačkoj županiji, jer stvarne vrijednosti prosjeka mogu biti bilo gdje unutar granica pouzdanosti, a granice pouzdanosti se za te dvije županije - i većinu ostalih - preklapaju.

Problemi s malim brojem ispitanika u županijama, odnosno slučajeva na individualnoj razini, te malim brojem županija, odnosno slučajeva na makrorazini, dovode u pitanje i analizu povezanosti. Prvo, prikazana analiza koja u obzir uzima raspone prosječnih vrijednosti prihvaćanja egalitarnog sindroma po županijama pokazuje da nema dovoljno varijabilnosti na zavisnoj varijabli koju bismo mogli testirati za povezanost $\mathrm{s}$ faktorima koje smatramo bitnima za njezino objašnjenje.

Drugo, čak i da taj problem zanemarimo i vodimo se rezultatima o povezanosti prosječne vrijednosti SEMA-27 i županijskog bruto domaćeg proizvoda, koje Burić i Štulhofer navode, autori izvještavaju o Pearsonovom korelacijskom koeficijentu od -0,27, odnosno -0,11 bez grada Zagreba. Riječ je o slaboj povezanosti koja, prema standardima u društvenim znanostima, nije uvjerljiva. Primjerice, kada spominju ograničenja analize koja proizlaze iz malog broja slučajeva uključenih u analizu (21 županija), Rimac, Burić i Štulhofer (2017) navode kako je Robert Putnam (Putnam i dr., 2003) svoju analizu o dinamici društvenog kapitala u Italiji temeljio na 20 regija, dakle također malom broju slučajeva. No, pritom ne spominju da se Putnam, nasuprot njima, oslanjao na niz raznovrsnih podataka i istraživačkih metoda te da je uključio različite razine analize. Isto tako ne spominju da su Putnamove korelacijske analize, prikazane uz uvjerljive grafikone raspršenosti, rezultirale izrazito visokim korelacijskim koeficijentima u rasponu stupnja povezanosti od 0,7 do 0,9.

Uzevši sve te probleme u obzir, za razliku od Štulhofera i Burića, ne smatramo opravdanim upuštati se u analizu hipoteze o kulturnoj inerciji ni graditi spoznaje na podacima koji su neprikladni za tu vrstu istraživačkih pitanja. Nadalje, navedeni se problemi uzorka ne mogu zaobići hijerarhijskom regresijskom analizom u dva koraka (Vuković, Štulhofer i Burić, 2017) i višerazinskim modeliranjem (Rimac, Burić i Štulhofer, 2017). Koliko nam je poznato, isti podaci su korišteni u tim kasnijim radovima, pa je važno istaknuti da nikakva napredna statistička analiza ne može popraviti podatke koji nisu prikladni za analizu koja se provodi ni nadomjestiti neprikladnost uzorka. Dapače, korištenje višerazinske regresijske analize na 21 županiji i s malim grupama ispitanika na individualnoj razini u naprednijim modelima rezultira umjetnom redukcijom standardnih pogrešaka i neizbježno dovodi do lažnih pozitivnih nalaza (Maas i Hox, 2005; Stegmueller, 2013). 


\section{Zaključak}

U ovom tekstu analizirale smo empirijski hommage Štulhofera i Burića (2015, 2016) Županovljevoj teoriji o egalitarnom sindromu. Slijedeći principe oblikovanja teorije u istraživački dizajn, pokazujemo da autori preskaču fundamentalne korake u tom procesu: prvi je zahtjev da se propozicije vlastite teze uklope u postojeće znanje o nekoj temi, a drugi da se obrazloži doseg svoje teorije. Budući da Štulhofer i Burić zanemaruju središnju važnost integracije TES-a u klasična i suvremena istraživanja u modernizacijskoj teoriji, prihvatile smo se tog zadatka u okviru koji dopušta časopisni tekst.

Pokazale smo da, dok kod Inkelesa i Smitha (1974) prepreku modernosti čini širok raspon tradicionalnih vrijednosti, Županovljeva teza svodi sindrom modernosti na preferencije prema redistribuciji, predrasude prema poduzetnicima i nepoštivanje vrijednosti ekspertize. Ako teorija modernizacije i brojna empirijska istraživanja fokus sindroma modernosti stavljaju na vrijednosti osobne autonomije, zašto su za Hrvatsku upravo okrenutost tržištu i poduzetništvu presudne za dostizanje modernosti? Na to pitanje nema odgovora ni nakon nove serije radova Štulhofera, Burića i suradnika. Osim toga, Županov sužava i drugi dio teze o modernizaciji poistovjećujući modernost s kapitalizmom, a Štulhofer i Burić se zadržavaju na istom terenu. Sindrom modernosti tako postaje egalitarni sindrom, a društveni razvoj postaje tržišno društvo. Istovremeno, modernizacijska teorija ni u klasičnoj ni u suvremenoj formulaciji ne identificira egalitarizam kao važnu prepreku razvoju. Možda Županovljeva teorija doista bolje objašnjava prepreke modernizaciji u Hrvatskoj od svih konkurentskih istraživanja vrijednosti, ali ako je tako, autori su to dužni argumentirati.

Odlučujući se za izradu vlastitih instrumenta za analizu, Štulhofer i Burić $(2015,2016)$ učvršćuju autarkični karakter TES-a. Županov je zanemario pitanje dosega svoje teorije, kako posežući za neopravdanim poopćavanjima tako i ograničavajući svoju teoriju na arbitraran način. Taj nam problem ostaje i nakon ove nove serije radova. Je li egalitarni sindrom fenomen koji pogađa samo Hrvatsku? Ako jest, kako to objašnjavamo? Ako nije, kako teorijski obrazlažemo doseg TES-a, posebno u svjetlu identificiranih diskrepancija sa suvremenim istraživanjima u modernizacijskoj teoriji?

Kao vlastiti prilog komparativnom istraživanju egalitarnog sindroma analiziramo dimenziju koja čini jezgru radikalnog egalitarizma kod Županova: aspiracije o dohotku. Pokazujemo kako nalazi njegovog istraživanja iz 1966. upućuju na suprotan zaključak od onoga koji je on izveo. Naime, najveće aspiracije za povećanjem dohotka pokazuju oni na dnu društvene ljestvice. Fizički radnici su, prema tome, prije nesputani homo economicus nego kočničari društvenog razvoja. Najvažnije, naša komparativna analiza dohodovne egalitarnosti pokazuje da smo u europskim i 
globalnim okvirima prosječno egalitarno orijentirani. Dapače, stanovnici Njemačke i Švicarske više, primjerice, teže uravnilovci nego stanovnici Hrvatske. Takav nalaz dovodi u pitanje interpretacije prema kojima je zahtjev za smanjenjem dohodovne nejednakosti atavizam socijalističke prošlosti, kao i one koje tvrde da zahtjevi za većom dohodovnom jednakošću koče razvoj društva. Kako objasniti snažniji zahtjev za smanjenjem dohodovne nejednakosti u Švicarskoj koja nikad nije bila socijalistička? Ili, kako objasniti zašto zahtjev za smanjenjem dohodovnih nejednakosti u Njemačkoj ne koči društveni razvoj? Sve u svemu, unošenje komparativne dimenzije u ovu raspravu značajno otežava teorijsku poziciju prema kojoj je uravnilovka glavna prepreka razvoju hrvatskog društva.

Pristup temi i postupke analize Štulhofera, Burića i suradnika u ovom smo radu okarakterizirale kao goli empiricizam ponajprije zato što zaklanja sva ova navedena pitanja, ali i zbog niza postupaka u njihovu dizajnu istraživanja. Dok Štulhofer i Burić $(2015,2016)$ ne raspravljaju o izboru metoda istraživanja, mi pokazujemo zašto su za empirijsku potkrepu TES-a potrebne, na primjer, analize političkih rascjepa i dinamike u odnosima među elitama. Anketnim upitnikom kao jedinom metodom istraživanja TES se ne može empirijski potvrditi već eventualno, uz uvjet da je mjerni instrument valjan, zahvatiti jedan njezin aspekt. Sljedeća teškoća s kojom se Štulhofer i Burić (2015) susreću jest Županovljeva karakterizacija egalitarnog sindroma ne samo kao višedimenzionalnog konstrukta nego i kao konstrukta višeg reda, odnosno latentne dimenzije treće razine. Osim što ne vode dovoljno računa o implikacijama te višedimenzionalnosti za svoju konceptualizaciju, autori pri izradi konfirmacijske faktorske analize s tri razine latentnih dimenzija preskaču postupke inkrementalne izgradnje modela. Kao što smo pokazale, poteškoće s kompleksnim modelom vide se kako u njihovim interpretacijama tako, na primjer, i u testiranju invarijantnosti. Prema našoj analizi (Prilog 1), njihov model egalitarnog sindroma ne zadovoljava uvjete konfiguracijske invarijantnosti među dobnim skupinama te se stoga ne može koristiti za testiranje hipoteza.

Naposljetku ukazujemo na slabosti analiza Štulhofera, Burića i suradnika koje proizlaze iz činjenice da podatke koje imaju ne bi trebali koristiti za analize koje poduzimaju. Uzorak anketnog istraživanja koji koriste reprezentativan je samo na razini države i ne bi se trebao koristiti za statističke testove na županijskoj razini. Osim toga, uzorak od 1000 ispitanika nedostatan je za takvu analizu jer se za neke županije prosječna vrijednost računa na temelju desetak ispitanika. Kao što pokazujemo, u većini županija zbog malog broja ispitanika koji čine uzorke unutar županija, rasponi granica oko izračunate prosječne vrijednosti su veliki i vrijednosti se preklapaju. Drugim riječima, ako u obzir uzmemo te raspone, upitno je postoje li uopće statistički značajne razlike u razinama prihvaćenosti egalitarnog sindroma među županijama. No, čak i da se vodimo rezultatima o povezanosti između pro- 
sječne vrijednosti SEMA-27 i županijskog bruto domaćeg proizvoda, koje autori navode, Pearsonov korelacijski koeficijent od -0,27 nije vrijednost temeljem koje bismo trebali tvrditi da smo ustanovili povezanost; posebno ako cijelo istraživanje temeljimo na jednoj vrsti analize. Navedeni problemi ne mogu se izbjeći ni hijerarhijskom regresijskom analizom u dva koraka ni višerazinskim modeliranjem.

Uzevši u obzir sve navedeno, zaključujemo da egalitarni sindrom ostaje teorijska fantazija svojih poklonika, a njegova eventualna empirijska validacija tek predstoji.

\section{PRILOG 1: Analiza invarijantnosti modela SEMA-15}

Ovdje se osvrćemo na jedan aspekt modeliranja Burića i Štulhofera (2016), analizu invarijantnosti modela SEMA-15, koji dobro ilustrira nedostatke empirijskih analiza autora i probleme koji proizlaze iz kompleksnosti modela TES-a.

Analiza invarijantnosti presudna je za TES jer, kako navode sami autori, "bez potvrde da razvijeni instrument podjednako dobro mjeri isti fenomen (egalitarni sindrom) u različitim dobnim skupinama, testiranje hipoteze o kulturalnoj perzistenciji nije izvedivo" (Burić i Štulhofer, 2016: 5). Važnost testiranja invarijantnosti mjernih instrumenata, prepoznata prije više od 50 godina, danas je neizostavan element znanstvenog proučavanja stavova i ponašanja (Putnick i Bornstein, 2016). Potreba testiranja invarijantnosti ili ekvivalentnosti mjerenja proizlazi iz činjenice da određene grupe često pridaju drugačije značenje istom fenomenu ili istim anketnim pitanjima. Ako želimo testirati postoji li "egalitarni sindrom” u Hrvatskoj, istražiti odnose između skale koju nude autori i nekih drugih fenomena ili usporediti rezultate različitih skupina ispitanika na konačnoj skali, to ne možemo napraviti ako invarijantnost nije zadovoljena. Ako mjera nije podjednako dobra za sve ključne skupine, bilo kakve razlike i povezanosti koje utvrdimo korištenjem skala mogu biti jednostavno rezultat lošeg mjerenja i modeliranja, to jest empirijski artefakt.

Iako Burić i Štulhofer (2016) provode test invarijantnosti kod populacijskog uzorka, za kompleksne modele s latentnim dimenzijama na više razina njihova analiza je neprikladna (Rudnev i dr., 2018) jer ne uzima u obzir kompleksnost postavljenog modela. Zato smo odlučile provesti novu analizu invarijantnosti modela SEMA-15 u kojoj je ona testirana inkrementalno, za svaku razinu mjernog i strukturnog djela modela, te cjelovito, testirajući sve tri razine na kojima se invarijantnost mora potvrditi prije korištenja skala: konfiguracijsku, mjernu i skalarnu. Burić i Štulhofer (2016) analizi invarijantnosti pristupaju usporedbom dvije skupine ispitanika: osobe sa 60 i više godina i osobe do 27 godina. Međutim, na temelju 
istraživanja formativnih razdoblja socijalizacije, koja pokazuju da su pojedinci od 18 do 25 godina još podložni većim promjenama stavova (Krosnick i Alwin, 1989; Bartels i Jackman, 2014), mislimo da je ispitanike s 18 ili 19 godina neprikladno tretirati kao "socijalizirane" u demokratskom tržišnom sustavu, kao što to čine autori. Odlučile smo analizom zahvatiti sve ispitanike starije od 26 godina, podijeljene $u$ pet dobnih skupina, kako bismo testirale mjeri li model podjednako dobro stavove u svim generacijama, odnosno jesu li zaključci o prisutnosti egalitarnog sindroma valjani za sve dobne skupine, kao što TES pretpostavlja.

Sukladno najnovijim preporukama, analizirale smo konfiguracijsku, mjernu i skalarnu invarijantnost (Chen, Sousa i West, 2005; Rudnev i dr., 2018). Konfiguracijska ili faktorska invarijantnost, najniža i najmanje restriktivna razina ekvivalentnosti, testira je li struktura latentnih dimenzija u izvornom "populacijskom" modelu jednaka među grupama. Drugim riječima, da bi se zadovoljio kriterij konfiguracijske invarijantnosti, čestice mjernog instrumenta trebaju imati podjednaku zasićenost na latentnim dimenzijama u svim dobnim skupinama. Konfiguracijska je invarijantnost potvrđena ako višegrupni model (multi-group CFA) u kojemu simultano testiramo isti model po svim grupama zadovoljava kriterije dobrog pristajanja. Mjerna invarijantnost testira pridaju li ispitanici iz različitih skupina jednako značenje latentnim dimenzijama, odnosno vidimo li kod svih skupina jednaka zasićenja čestica. Test mjerne invarijantnosti obično se provodi tako da se zasićenja čestica fiksiraju na jednaku vrijednost za sve grupe. Međutim, u kontekstu višerazinskih modela, kao što je SEMA-15, koriste se dvije verzije mjerne invarijantnosti: u prvom testu fiksiraju se vrijednosti zasićenja čestica, a u drugom i zasićenja latentnih komponenti egalitarnog sindroma. Posljednji test, skalarna invarijantnost, predstavlja najvišu razinu ekvivalencije i testira imaju li pojedinci koji imaju jednake rezultate na latentnim dimenzijama i jednake rezultate na česticama mjernog instrumenta, bez obzira na grupnu pripadnost (Chen, Sousa i West, 2005; Brown, 2015; Rudnev i dr., 2018). Test pretpostavlja fiksiranje zasićenja čestica, ali i fiksiranje odsječka na osi y čestica za sve skupine. Ograničenja koja se postavljaju tim modelom osiguravaju da su prosječne vrijednosti čestica rezultat razlika u prosječnim vrijednostima latentnih dimenzija, a ne u zasićenjima čestica. Kao i kod mjerne invarijantnosti, skalarna invarijantnost testira se najprije za dimenzije prvog reda, a potom za dimenzije prvoga i drugog reda.

Rezultati analize su prikazani u Tablici 1.

Analiza pokazuje da model egalitarnog sindroma (SEMA-15) ne zadovoljava uvjete konfiguracijske invarijantnosti među dobnim skupinama (SRMR $=0,12$; RMSEA $=0,04 ;$ CFI $=0,86$ ). Faktorska struktura, koju testiraju Štulhofer i Burić, nije ekvivalentna među dobnim skupinama. Budući da je konfiguracijska invarijantnost najmanje restriktivna i najniža razina ekvivalencije, u praksi se kod takvih 
Tablica 1. Provjera dobne invarijantnosti modela sa 5 latentnih dimenzija i 15 čestica (SEMA-15)

\begin{tabular}{|c|c|c|c|c|c|c|c|c|c|c|}
\hline & $\begin{array}{l}\text { Razina analize } \\
\text { invarijantnosti }\end{array}$ & $\chi^{2}$ & Df & RMSEA & CFI & $\Delta \mathrm{CFI}$ & SRMR & $\Delta \chi^{2}$ & $\Delta \mathbf{d f}$ & $\mathbf{p}$ \\
\hline M1 & $\begin{array}{l}\text { Konfiguracijska } \\
\text { invarijantnost }\end{array}$ & 1030,88 & 425 & 0,04 & 0,86 & & 0,12 & & & \\
\hline M2 & $\begin{array}{l}\text { Mjerna invarijantnost } \\
\text { dimenzija I. reda }\end{array}$ & 1071,34 & 465 & 0,04 & 0,86 & 0,00 & 0,11 & 40,45 & 40 & 0,45 \\
\hline M3 & $\begin{array}{l}\text { Mjerna invarijantnost } \\
\text { dimenzija I. i II. reda }\end{array}$ & 1092,04 & 481 & 0,04 & 0,86 & 0,00 & 0,10 & 20,71 & 16 & 0,19 \\
\hline M4 & $\begin{array}{l}\text { Skalarna invarijantnost } \\
\text { dimenzija I. reda }\end{array}$ & 1159,68 & 524 & 0,04 & 0,85 & 0,01 & 0,16 & 67,64 & 43 & 0,01 \\
\hline M5 & $\begin{array}{l}\text { Skalarna invarijantnost } \\
\text { dimenzija I. i II. reda }\end{array}$ & 2692,75 & 546 & 0,07 & 0,51 & 0,35 & 0,23 & 1533,07 & 22 & 0,00 \\
\hline
\end{tabular}

Napomene: Modeli su testirani na temelju predloška inicijalnog modela SEMA-15 (Štulhofer i Burić, 2015 i 2016) konfirmatornom faktorskom analizom u programskim paketima IBM SPSS 23 i AMOS 23. Svi podaci su "otežani" u skladu s preporukama autora, te su sve analize provedene na matrici kovarijanci. $\mathrm{N}=1000\left(\mathrm{~N}_{26-35}=163, \mathrm{~N}_{36-45}=153, \mathrm{~N}_{46-55}=162, \mathrm{~N}_{56-65}=184, \mathrm{~N}_{66+}=171\right)$. U skladu s preporukama granične vrijednosti procjene pristajanja modela su sljedeće: RMSEA manje od 0,05 kao dobro pristajanje, RMSEA manje od 0,05-0,08 kao umjereno pristajanje, RMSEA manje od 0,08-0,10 kao marginalno pristajanje (Hu i Bentler, 1999); CFI vrijednosti između 0,90-0,95 kao prihvatljivo pristajanje, a vrijednosti veće od 0,95 kao dobro pristajanje (ibid.), te SRMR vrijednost 0 kao savršeno pristajanje, a vrijednosti manje od 0,08 kao prihvatljivo pristajanje (ibid.).

nalaza ne provode nove analize invarijantnosti, inicijalni model se odbacuje ili, ako je to moguće, modificira. Nadalje, iako su rezultati $\chi 2$ testa pozitivni, kriteriji pristajanja modela mjerne invarijantnosti nisu potpuno zadovoljeni. Najlošiji rezultati vidljivi su kod testiranja skalarne invarijantnosti, koja nedvojbeno nije potvrđena (M4 $\Delta \chi^{2}=67,64 ; \Delta d f=43 ; p>0,01$, M5 $\Delta \chi 2=1533,07 ; \Delta d f=22 ; p>0,00$ ). Iako su Burić i Štulhofer (2016: 5) predstavili mjerni instrument SEMA-15 kao model koji "podjednako dobro mjeri fenomen egalitarnog sindroma u bitno različito socijaliziranim generacijama", rezultati prikazani u Tablici 1. neizbježno nas navode na drugačiji zaključak. 


\section{LITERATURA}

Acemoglu, Daron i Robinson, James A. 2012. Why Nations Fail: The Origins of Power, Prosperity and Poverty. Crowne Business Publishing. New York.

Adcock, Robert i Collier, David. 2001. Measurement validity: A shared standard for qualitative and quantitative research. American Political Science Review, (95), 3: 529-546.

Bartels, Larry i Jackman, Simon. 2014. A generational model of political learning. Electoral Studies, (2014), 33: 7-18.

Bollen, Kenneth, i Lennox, Richard. 1991. Conventional wisdom on measurement: A structural equation perspective. Psychological Bulletin, (110), 2: 305-314.

Bourdieu, Pierre. 1988. Vive la Crise!: For Heterodoxy in Social Science. Theory and Society, 17 (5): 773-787.

Brown, Timothy. 2015. Confirmatory Factor Analysis for Applied Research, Second Edition. The Guilford Press. New York.

Burić, Ivan. 2017. Theoretical Reflections on the Possible Causes of Egalitarian Syndrome Inertia. Revija za sociologiju, (47), 3: 335-359.

Burić, Ivan i Štulhofer, Aleksandar. 2016. In search of the egalitarian syndrome: cultural inertia in Croatia? Financial Theory and Practice, (40), 4: 361-382.

Chen, Fang Fang, Sousa, Karen H. i West, Stephen G. 2005. Teacher's corner: Testing measurement invariance of second-order factor models. Structural Equation Modeling, (12), 3: 471-492.

Clark, Andrew E. i D'Ambrosio, Conchita. 2014. Good, better, best. The social context of labour-market success. IARIW 33rd General Conference. Rotterdam.

Coppedge, Michael. 2012. Democratization and research methods. Cambridge University Press. Cambridge.

Corbetta, Piergiorgio. 2003. Social research: Theory, methods and techniques. Sage. New York.

Dolenec, Danijela. 2012. Democratic Institutions and Authoritarian Rule in Southeast Europe. ECPR Press. Colchester.

Dolenec, Danijela. 2013. Nakon Apsurdistana, Florida, dostupno na http://www.h-alter. org/vijesti/nakon-apsurdistana-florida. Zadnji put pristupljeno: 10. lipnja 2018.

Dolenec, Danijela. 2014. Preispitivanje "egalitarnog sindroma” Josipa Županova. Politička misao, 51 (4): 41-64.

Dolenec, Danijela. 2016. Nakon devijantne modernizacije, divlji kapitalizam? Genealogija teze i neke kritičke opaske, u: Sekulić, D. (ur.): Vrijednosti u hrvatskom društvu. Centar za demokraciju i pravo Miko Tripalo. Zagreb: 91-109.

Doolan, Karin. 2016. Kako je rasprava o Županovljevu radu istaknula podjele u (hrvatskoj) sociologiji? Revija za sociologiju, (46): 161-170. 
Eagleton, Terry. 2011. Why Marx Was Right. Yale University Press. New Heaven.

Grdešić, Marko. 2016. Piketty, economics and sociology: The analytical and political agenda on inequality. Anali Hrvatskog politološkog društva: časopis za politologi$j u,(12), 1: 115-132$.

Hall, Peter A. i Taylor, Rosmary C. R. 1996. Political Science and the Three New Institutionalisms. Political Studies, (44), 5: 936-957.

Harrison, David. 1988. The Sociology of Modernization and Development. Routledge. London.

Harrison, Lawrence E. 2000. Introduction, u: Harrison, L. E. i Huntington, S. P. (ur.): Culture Matters: How Values Shape Human Progress. Basic Books. New York: xvii-xxxiv.

Hodžić, Alija i Krištofić, Branimir. 2014. Istraživanja socijalne strukture, u: Branović, B. i Ilišin, V. (ur.): Institut za društvena istraživanja u Zagrebu 1964.-2014. IDIZ. Zagreb: 61-64.

Horvat, Branko. 1969. Ogled o jugoslavenskom društvu. Mladost. Zagreb.

Hu, Li-tze i Bentler, Peter M. 1999. Cutoff criteria for fit indexes in covariance structure analysis: Conventional criteria versus new alternatives. Structural Equation Modeling: a Multidisciplinary Journal, (6), 1: 1-55.

Inglehart, Ronald. 2018. Modernization, Existential Security and Cultural Change: Reshaping Human Motivations and Society, u: Gelfand, M. J., Chiu, C. i Hong, Y. (ur.): Handbook of Advances in Culture and Psychology, Volume 7. Oxford University Press. Oxford: 1-53.

Inglehart, Ronald i Welzel, Christian. 2007. Modernizacija, kulturna promjena i demokracija. Politička kultura. Zagreb.

Inkeles, Alex i Smith, David H. 1974. Becoming Modern: Individual Changes in Six Developing Countries. Harvard University Press. Cambridge.

Ivanković, Željko i Šonje, Velimir. 2011. Nedemokratski kapitalizam i nova tranzicija. Zagrebački ekonomski forum - Friedrich Ebert Stiftung. Zagreb.

Johnson, Russel E., Rosen, Christopher C., Chang, Chu-Hsiang, Djurdjevic, Emilija i Taing, Meng U. 2012. Recommendations for improving the construct clarity of higher-order multidimensional constructs. Human Resource Management Review, (2012), 2: 62-72.

Jöreskog, Karl G. 1969. A general approach to confirmatory maximum likelihood factor analysis. Psychometrika, (34): 183-202.

Jöreskog, Karl G. 1970. A general method for analysis of covariance structures. Biometrika, (57): 239-251.

Katunarić, Vjeran. 2004. Vrijediti i koštati: sociokulturne pretpostavke tranzicije u novijim radovima hrvatskih ekonomista. Društvena istraživanja, (13), 1-2: 69-70. 
Kempner, Joanna, Merz, Jon F. i Bosk, Charles L. 2011. Forbidden Knowledge: Public Controversy and the Production of Nonknowledge 1. Sociological Forum, (26), 3: 475-500.

King, Gary, Keohane, Robert O. i Verba, Sidney. 1994. Designing Social Inquiry: Scientific Inference in Qualitative Research. Princeton University Press. Princeton, New Jersey.

Krosnick, Jon A. i Alwin, Duane F. 1989. Aging and susceptibility to attitude change. Journal of Personality and Social Psychology, (57), 3: 416-425.

Lalić, Dražen. 2005. Osobit potpis Josipa Županova kao istraživača suvremenoga hrvatskog društva. Revija za sociologiju, (36), 3-4: 141-148.

Law, Kenneth S., Wong, Chi-Sum i Mobley, William M. 1998. Toward a taxonomy of multidimensional constructs. Academy of Management Review, (23), 4: 741-755.

Levačić, Dora. 2016. Preispitivanje koncepta egalitarnog sindroma Josipa Županova. Politička misao, (53), 1: 164-168.

Lim, Timothy C. 2010. Doing Comparative Politics: An Introduction to Approaches and Issues. Lynne Rienner Publishers. London.

Lim, Timothy C. 2016. Doing Comparative Politics: An Introduction to Approaches and Issues. Third Edition. Lynne Rienner Publishers. London.

Maas, Cora J. M. i Hox, Joop J. 2005. Sufficient sample sizes for multilevel modeling. Methodology, (1), 3: 86-92.

Novokmet, Filip. 2017. Between communism and capitalism: essays on the evolution of income and wealth inequality in Eastern Europe 1890-2015. Doktorska disertacija. Ecole des Hautes Etudes en Sciences Sociales, Pariz.

Peters, B. Guy. 2007. Institucionalna teorija u političkoj znanosti: novi institucionalizam. Fakultet političkih znanosti. Zagreb.

Popović, Mihailo V., Bolčić, Silvano, Pešić, Vesna, Janićijević, Miloslav i Pantić, Dragomir. 1977. Društveni slojevi i društvena svest. Centar za sociološka istraživanja Instituta društvenih nauka. Beograd.

Putnam, Robert, Leonardi, Robert i Nanetti, Raffaella. 2003. Making Democracy Work: Civic Traditions in Modern Italy. Princeton University Press. Princeton.

Putnick, Diane L. i Bornstein, Marc H. 2016. Measurement invariance conventions and reporting: the state of the art and future directions for psychological research. Developmental Review, 41: 71-90.

Rhodes, R. A. W. 1995. The Institutional Approach, u: Marsh, D. i Stoker, G. (ur.): Theory and Methods in Political Science. Palgrave Macmillan. Basingstoke: 42-57.

Rimac, Ivan, Burić, Ivan i Štulhofer, Aleksandar. 2017. Višerazinsko modeliranje egalitarnog sindroma i validacija kratke skale SEMA-5. Politička misao, (54), 3: 64-79.

Rostow, Walt Whitman. 1960. The Stages of Economic Growth: A Non-Communist Manifesto. Cambridge University Press. Cambridge. 
Rudnev, Maksim, Lytkina, Ekaterina, Davidov, Eldad, Schmidt, Peter i Zick, Andreas. 2018. Testing Measurement Invariance for a Second-Order Factor. A Cross-National Test of the Alienation Scale. Methods, Data, Analyses, (12), 1: 47-76.

Rus, Veljko. 1966. Klike u radnim organizacijama. Gledišta, 8/9.

Sartori, Giovanni. 1984. Social science concepts: a systematic analysis. Sage Publications. New York.

Schneider, S. M. 2012. Income Inequality and its Consequences for Life Satisfaction: What Role do Social Cognitions Play? Social Indicators Research, 106: 419-438.

Sekulić, Duško. 2012. Društveni okvir i vrijednosni sustav. Revija za sociologiju, (42), 3: 231-275.

Sekulić, Duško. 2016. Vrijednosti u hrvatskom društvu. Centar za demokraciju i pravo Miko Tripalo. Zagreb.

Shweder, Richard A. 2000. Moral Maps, "First World" Conceits and the New Evangelists, u: Harrison, L. E. i Huntington, S. P. (ur.): Culture Matters: How Values Shape Human Progress. Basic Books. New York.

Stegmueller, Daniel. 2013. How many countries for multilevel modeling? A comparison of frequentist and Bayesian approaches. American Journal of Political Science, (57), 3: 748-761.

Swidler, Ann. 1986. Culture in Action: Symbols and Strategies. American Sociological Review, (51), 2: 273-286.

Šporer, Željka. 2001. Protuslovlja globalizacije, u: Meštrović, M. (ur.): Globalizacija $i$ njene refleksije u Hrvatskoj. Ekonomski institut. Zagreb.

Šram, Zlatko. 2008. Ideologijska strukturiranost socijalno-ekonomskih orijentacija. Revija za socijalnu politiku, (15), 2: 209-223.

Šram, Zlatko. 2014. Eksplorativna i konfirmatorna faktorska analiza skale nacionalističkog sindroma (sns-1). Političke perspektive, (4), 1: 7-30.

Štulhofer, Aleksandar 2000. Nevidljiva ruka tranzicije: ogledi iz ekonomske sociologije. HSD, Biblioteka časopisa Socijalna ekologija. Zagreb.

Štulhofer, Aleksandar. 2001. Dinamika sociokulturnog kapitala u Hrvatskoj: 1995-1999, u: Meštrović, M. (ur.): Globalizacija i njene refleksije u Hrvatskoj. Ekonomski institut. Zagreb: 219-228.

Štulhofer, Aleksandar i Burić, Ivan. 2015. Je li egalitarni sindrom samo teorijska fantazija? Empirijski hommage Josipu Županovu. Politička misao, (52), 3: 7-31.

Švarc, Jadranka i Lažnjak, Jasminka. 2017. Innovation Culture in Crony Capitalism. Institut za društvena istraživanja Ivo Pilar. Zagreb.

Tadić, Darinka i Županov, Josip. 1969. Ekonomske aspiracije i društvena norma egalitarnosti. Sociologija, (11), 2: 279-305.

Vuković, Vuk, Štulhofer, Aleksandar i Burić, Ivan. 2017. Je li Županov imao pravo? Testiranje podrijetla i perzistencije egalitarnog sindroma. Društvena istraživanja, (26), 2: 207-225. 
Zeman, Zdenko. 1998. Antinomije moderne: filozofijske i sociologijske refleksije, u: Rogić, I. i Zeman, Z. (ur.): Privatizacija i modernizacija. Institut društvenih znanosti Ivo Pilar. Zagreb: 11-34.

Županov, Josip. 1987a. Egalitarizam i industrijalizam, u: Sociologija i samoupravljanje. Školska knjiga. Zagreb: 26-85.

Županov, Josip. 1987b. Radikalni egalitarizam kao društveni kod, u: Sociologija i samoupravljanje. Školska knjiga. Zagreb: 86-102.

Županov, Josip. 1995. Poslije potopa. Globus. Zagreb.

\author{
Danijela Dolenec, Daniela Širinić \\ STILL A THEORETICAL FANTASY: \\ JOSIP ŽUPANOV'S EGALITARIAN SYNDROME
}

\begin{abstract}
Summary
In this article we analyse Štulhofer and Burić's empirical hommage (2015, 2016) to Županov's egalitarian syndrome theory (EST). We show that the authors neglect fundamental steps in research design, including the imperative of situating their argument within the existing research on the topic. Furthermore, the authors fail to fully acknowledge the implications of the multidimensionality of EST, both in their conceptualisation and in their choice of statistical analyses. We show why the data that they use are not appropriate for the analyses that they undertake. In contrast to that, in our comparative analysis of income inequality preferences across countries Croatian citizens turn out to be quite average. Citizens of Germany or Switzerland seem to be more strongly oriented towards income equality ("uravnilovka") than citizens of Croatia. These findings clearly challenge interpretations according to which preferences for greater income equality are remnants of a socialist past, or those according to which such demands pose obstacles to societal development. Taking all this on board, we conclude that the egalitarian syndrome theory remains a theoretical fantasy.
\end{abstract}

Keywords: egalitarian syndrome theory, modernization theory, research design, income inequality, Croatia

Danijela Dolenec je docentica na Fakultetu političkih znanosti Sveučilišta u Zagrebu. Daniela Širinić je docentica na Fakultetu političkih znanosti Sveučilišta u Zagrebu.

Kontakti:

Danijela Dolenec, Fakultet političkih znanosti, Lepušićeva 6, 10000 Zagreb. E-mail: danijela.dolenec@fpzg.hr

Daniela Širinić, Fakultet političkih znanosti, Lepušićeva 6, 10000 Zagreb. E-mail: daniela.sirinic@fpzg.hr 